\title{
ROULA KOZAK
}

Terapia fotodinâmica para tratamento de carcinoma basocelular do tipo nodular: estudo comparativo entre o ácido 5-aminolevulínico (ALA) em nanoemulsão e o metil-ALA

Dissertação de Mestrado submetida ao Programa de Pós-graduação em Nanociência e Nanobiotecnologia da Universidade de Brasília, como parte integrante dos requisitos para a obtenção do título de Mestre em Nanociência e Nanobiotecnologia.

Orientadora: Profa. Dra. Zulmira Guerrero Marques Lacava.

Brasília-DF

2014 
UNIVERSIDADE DE BRASÍLIA

INSTITUTO DE CIÊNCIAS BIOLÓGICAS

PROGRAMA DE PÓS-GRADUAÇÃO EM NANOCIÊNCIA E NANOBIOTECNOLOGIA

Dissertação de Mestrado

Roula Kozak

Título:

"Terapia Fotodinâmica para tratamento de carcinoma basocelular do tipo nodular: estudo comparativo entre o ácido 5-aminolevulínico (ALA) em nanoemulsão e o metil-ALA."

Comissão Examinadora:

Profa. Dra. Zulmira Guerrero Marques Lacava

Presidente

UnB / PGNano

Profa. Dra. Maria de Fátima M. A. Santos

Membro Titular Interno não Vinculado ao

Programa

Unb/PGNano
Profa. Dra. Rosângela Vieira de Andrade

MembroTitular Externo não vinculado ao programa $U C B / D F$

Brasília, 17 de dezembro de 2014. 
A tudo e todas as pessoas que fizeram diferença na minha vida.

À ciência da vida.

À vida. 


\section{AGRADECIMENTOS}

À minha orientadora, a Profa. Dra. Zulmira Guerrero Marques Lacava, por estar sempre presente e me ajudando a superar todas as dificuldades. Obrigado por ser uma grande amiga e excelente professora.

À amiga e colega de profissão Simone Karst Passos, pelo exemplo de entusiasmo e pela confiança.

Ao primo e verdadeiro amigo Cezar Kozak Simaan, que se faz presente sempre que solicito. Sua presença faz a diferença.

À Profa. Isabel Cristina Rodrigues da Silva, pela valiosa análise estatística.

À Luci Ramira da Silva, pela incansável e pronta ajuda sempre que solicitada durante a execução desse trabalho. Obrigado por tantas vezes telefonar, agendar consultas, desmarcar, encaminhar lâminas e materiais, etc.

Aos colegas Dr. Alesso Cervantes Sartorelli e Dr. Luis Eduardo de Almeida Prado Franceschi, por abrir as portas do laboratório Diagnose e pela recepção simpática.

Ao Dr. Luis Eduardo de Almeida Prado Franceschi pela colaboração indispensável examinando e revisando minuciosamente todas as lâminas para o exame histopatológico nesse trabalho.

À minha querida Patrícia Eliane da Silva, auxiliar exemplar, atenciosa e delicada com os pacientes.

Ao Eduardo Henrique Kouzak Oliveira, médico residente à época do estudo e primo mais novo; pela disponibilidade e ajuda nas buscas de referências bibliográficas.

Aos demais colegas, médicos residentes e funcionários do serviço de Dermatologia do HRAN que, direta ou indiretamente, contribuíram para a elaboração deste trabalho. 
"A inteligência é a primeira energia do universo, e os modos de fazer ciência são infinitos. A essência da ciência é que, mais que verdadeira, deve ser funcional, deve resolver, deve ser racionalidade ao concreto, racionalidade ao resultado, à solução." Antonio Meneghetti. São Paulo, 2007. 


\section{RESUMO}

KOZAK, R. Terapia fotodinâmica para tratamento de carcinoma basocelular do tipo nodular: estudo comparativo entre o ácido 5-aminolevulínico (ALA) em nanoemulsão e o metil-ALA. 2014. Dissertação (Mestrado em Nanociência e Nanotecnologia). Instituto de Ciências Biológicas, Universidade de Brasília, Brasília, 2014.

A terapia fotodinâmica (TFD) é uma modalidade importante não invasiva no tratamento de casos selecionados de carcinoma basocelular, a neoplasia maligna mais frequente em humanos. A eficácia da TFD no tratamento do carcinoma basocelular nodular ( $\mathrm{CBCn}$ ) não está bem estabelecida, havendo taxas de cura e recorrência variáveis na literatura. A melhora da ação dos agentes fotossensibilizantes em termos de especificidade, potência e penetração cutânea constitui uma importante perspectiva para o aprimoramento da TFD. Nesse aspecto, a nanotecnologia e seu potencial em aprimorar os sistemas de liberação de fármacos são bastante promissores. No presente trabalho, foi estudada a eficácia e tolerabilidade de dois precursores fotossensibilizantes no tratamento do carcinoma basocelular nodular com até $2 \mathrm{~mm}$ de profundidade, o ácido aminolevulínico em nanoemulsão lipídica polimérica, o Nano-ALA, e o metil-aminolevulinato, o M-ALA. Participaram do estudo 24 pacientes com o total de 30 lesões de $C B C n$, divididos aleatoriamente em dois grupos de tratamento. Foram realizadas duas sessões padronizadas de TFD com intervalo de uma semana e após três meses foi realizada excisão cirúrgica da área tratada: 26 lesões (86,7\%) localizavam-se em face e 16 $(53,3 \%)$ situavam-se em área de alto risco. No total, a taxa de cura histológica foi de $50 \%$ e não houve diferença significativa entre os dois grupos (M-ALA $=62,5 \%$ e Nano-ALA $=35,7 \% ; P=0,14$ ). Alguns fatores podem ter influenciado negativamente nesse resultado do Nano-ALA, como maior número de lesões em áreas de alto risco e a presença de tipos e subtipos diferentes do CBCn nesse grupo. $O$ tratamento em geral foi bem tolerado, com escores de dor, eritema e edema semelhantes nos dois grupos. O único preditor de má resposta encontrado foi a localização do tumor em áreas de alto risco. Em conclusão, o desempenho do Nano-ALA em termos de eficácia e tolerabilidade foi semelhante ao do M-ALA na TFD para CBCn. A taxa de cura relativamente baixa no presente trabalho reforça que a TFD no tratamento do $\mathrm{CBC}$ deve ser indicada em casos selecionados e usada com cautela.

Palavras-Chave: Terapia fotodinâmica. Carcinoma basocelular nodular. Ácido aminolevulínico. Nanoemulsão. M-ALA. ALA. Nano-ALA. 


\section{ABSTRACT}

KOZAK, R. Photodynamic therapy for treatment of nodular basal cell carcinoma: comparative study between 5-aminolevulínicon acid (ALA) in nanoemulsion and Metil-ALA. 2014. Thesis (Masters in Nanoscience and Nanotechnology). Instituto de Ciências Biológicas, Universidade de Brasília, Brasília, 2014.

Photodynamic therapy (PDT) is an important noninvasive strategy of treatment for selected cases of basal cell carcinoma (BCC), the commonest malignancy in humans. The efficacy of PDT in the treatment of nodular BCC (BCCn) is not established, with cure and recurrence rates highly variable. The improvement of photosensitizing agents in terms of specificity, potency and skin penetration is an important perspective for achieving better results with PDT. In this regard, Nanotechnology and its potential in improving drug releasing systems are very promising. In this study, the efficacy and side effects of two photosensitizing precursors in the treatment of BBCnup to $2 \mathrm{~mm}$ deep were investigated, the aminolevulinic acid in polymeric lipid nanoemulsion, the Nano-ALA, and methylaminolevulinate, the M-ALA. The study included 24 patients with a total of $30 \mathrm{BCCn}$ lesions, randomly divided into two treatment groups. Two standard PDT sessions were performed one week apart and three months later the treated area underwent surgical excision. 26 lesions (86.7\%) were located in the face and $16(53.3 \%)$ were at high risk area. In total, the histological cure rate was $50 \%$ and there was no significant difference between the two groups (M-ALA $=62.5 \%$ and Nano-ALA $=$ $35.7 \% ; P=0.14)$. Some factors may have impaired Nano-ALA results, such as a greater number of lesions at high risk areas and the presence of different types and subtypes of BCCn in this group. The treatment was overall well tolerated, with pain scores, erythema and edema similar in both groups. The only poor response predictor was the location of the tumor in high-risk areas. In conclusion, the performance of Nano-ALA in terms of efficacy and tolerability was similar to that of MALAin PDT for BCCn. The relatively low cure rate in this study suggests that PDT in the treatment of $\mathrm{CBCn}$ should be indicated in selected cases and used with caution.

Key words: Photodynamic therapy. Nodular basal cell carcinoma. Aminolevulinic acid. Methyl-aminolevulinate. Nanoemulsion. ALA. MAL. Nano-ALA. 


\section{LISTA DE FIGURAS E GRÁFICOS}

Figura 1 - Esquema representativo de via hedgehog (SHH - proteína sonichedgehog; PTCH - receptor patchedhedgehog; SMO receptorsmoothened; GLI - fator GLI-1; TGF $\beta$ - fator transformador de crescimento tipo $\beta$; WNT - via sinalizadora wingless; BMP - proteína morfogenética óssea.Adaptado de CHINEM; MIOT, 2011

Figura 2 - Áreas de alto risco para recidivas na face representada pela cor vermelha da face (área "H"). Adaptado de MOSTERD et al, 2008). Imagem de fundo obtida em www.symbiosysart.com.........

Figura 3 - Representação esquemática dos mecanismos de penetração percutânea de fármacos (adaptado de BARRY, 2004).

Figura 4 - Fotos llustrativas da apresentação clinica de CBC nodular em quatro participantes da pesquisa. Destaca-se a multiplicidade das lesões vista na última foto (Fotografias de autoria da pesquisadora)

Figura 5 - Fotos ilustrativas do processo de M-ALA-TFD de dois participantes da pesquisa. Da esquerda para direta: (A) lesão pré-tratamento, (B) fluorescência na primeira sessão, (C) fluorescência na segunda sessão e (D) lesão 3 meses após o tratamento. Destaca-se a maior intensidade da fluorescência na segunda sessão em relação à primeira. (Fotografias de autoria da pesquisadora).

Gráfico 1- Distribuição das lesões conforme tamanho e espessura antes da terapia fotodinâmica

Gráfico 2 - Dor na primeira e na segunda sessão de TFD no grupo tratado com nano-ALA e no grupo tratado com M-ALA. Valores mínimo e máximo (extremidades), percentis 25 e 75 (limites do retângulo) e mediana traço horizontal central)... 


\section{LISTA DE TABELAS}

Tabela 1 - Critérios de risco e classificação do carcinoma basocelular nodular.

Tabela 2 - Protocolos de TFD utilizados no estudo.

Tabela 3 - Características dos sujeitos da pesquisa quanto ao sexo, tipo de pele, e cor dos olhos nos grupos de tratamento

Tabela 4 - Distribuição das lesões quanto à localização em tronco ou face e em área de risco nos dois grupos de tratamento, antes da intervenção.

Tabela5 - Tamanho da lesão e espessura histológica do tumor antes da terapia fotodinâmica nos dois grupos de tratamento

Tabela6 - Espessura do tumor em áreas de alto risco ou de baixo risco antes da intervenção com terapia fotodinâmica

Tabela 7 - Espessura do tumor em áreas de alto risco ou de baixo risco nos dois grupos de tratamento antes da intervenção com terapia fotodinâmica

Tabela 8 - Cura clínica e histológica após a terapia fotodinâmica

Tabela 9 - Espessura do tumor nos dois grupos de tratamento antes e após a terapia fotodinâmica.

Tabela 10 - Cura clínica versus cura histológica nos grupos de tratamento.

Tabela 11 - Cura histológica estratificada por área de risco, tamanho e espessura das lesões antes da terapia, e pela faixa etária do paciente.

Tabela 12 - Eventos adversos (dor, edema e eritema) nos dois grupos de tratamento na primeira e na segunda sessão de TFD

Tabela 13 - Comparação intragrupo do eritema e edema após a primeira e segunda sessões de TFD nos dois grupos de tratamento. 


\section{LISTA DE ABREVIATURAS}

ALA Ácido 5-aminolevulínico

ALA-TFD Terapia fotodinâmica realizada com ácido 5-aminolevulínico

BMP Proteína morfogenética óssea

CBC Carcinoma basocelular

CBCn Carcinoma basocelular tipo nodular

CBCs Carcinoma basocelular tipo superficial

DNA Ácido desoxirribonucléico

EP Erro padrão

FDA Food and Drug Administration

FS Fotossensibilizador

GLI $\quad$ Fator GLI-1

$\mathrm{HH} \quad$ Família de proteínas hedgehog

HSP Proteínas de choque térmico

IL Interleucina

LED Luz emitida por diodo

M-ALA Metilaminolevulinato ou Metil-ALA (Metvix®)

M-ALA-TFD Terapia fotodinâmica realizada com metilaminolevulinato.

Nano-ALA Ácido 5-aminolevulínico em nanoemulsão a 20\%

Nano-ALA-TFD Terapia fotodinâmica realizada com ácido 5-aminolevulínico em nanoemulsão a $20 \%$

PplX Protoporfirina 9

PTCH Receptor patchedhedgehog

$\mathrm{SHH} \quad$ Proteína sonic hedgehog

SMO Receptor smoothened

Spot Cabeça aplicadora com luz emitida por diodo do aparelho Multiwaves, INDUSTRA-Brasil.

Spot PDT Cabeça aplicadora com luz emitida por diodo para "photodinamic therapy" 
Spot RED

Cabeça aplicadora com luz emitida por diodo da cor vermelha "RED"

TFD

Terapia fotodinâmica

TGF $\beta$

Fator transformador de crescimento tipo $\beta$

TNF- $\alpha$

Fator de necrose tumoral $\alpha$

UV

Radiação ultravioleta

UVA

Radiação ultravioleta $\mathrm{A}$

UVB

Radiação ultravioleta B

WNT

Via sinalizadora wingless 


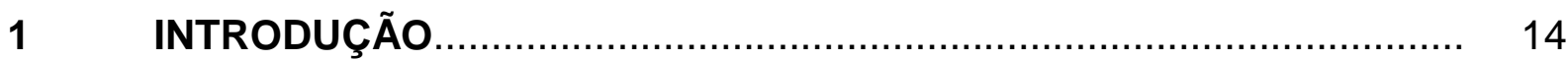

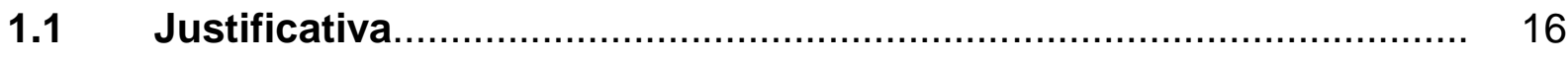

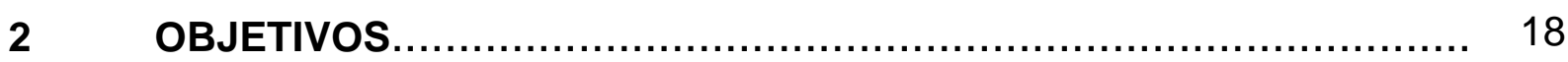

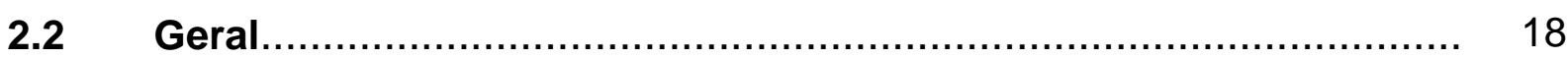

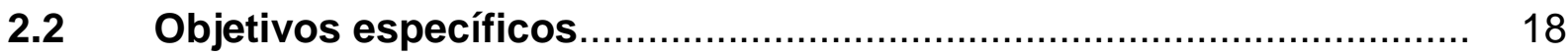

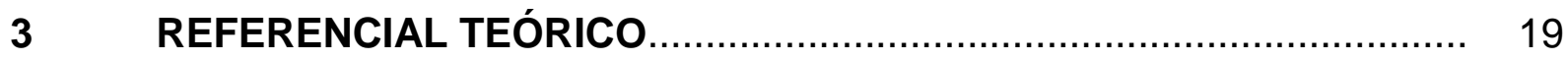

3.1 Carcinoma basocelular.......................................................... 19

3.2 Terapia fotodinâmica............................................................... 26

3.3 Fármacos fotossensibilizantes ...................................................... 34

3.4 Nanobiotecnologia................................................................ 36

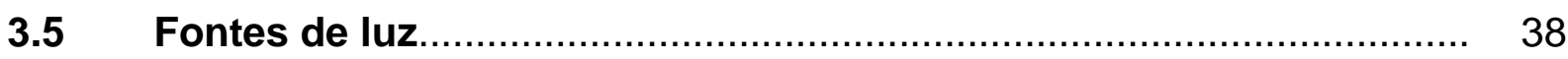

$4 \quad$ MATERIAL E MÉTODOS ................................................................. 41

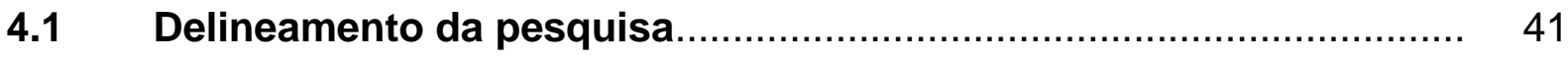

4.1.1 Amostras fotossensibilizantes................................................ 41

4.1.2 Participantes e local da pesquisa ............................................... 42

4.2 Procedimentos de coleta de dados ............................................... 43

4.2.1 Preparo das lesões, coleta da amostra e TFD................................. 43

4.2.2 Avaliação da eficácia e seguimento ............................................... 44

4.2.3 Avaliação de tolerabilidade ........................................................... 45

4.2.3.1 Avaliação da dor ..................................................................... 45 
4.2.3.2 Avaliação de outros efeitos adversos......................................... 45

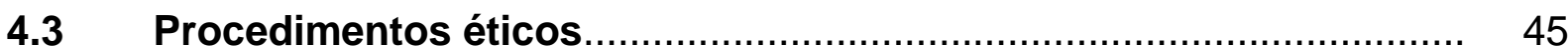

$4.4 \quad$ Análise estatística ..................................................................... 45

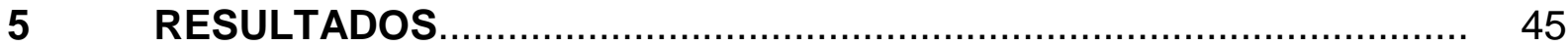

5.1 Caracterização clínica do carcinoma basocelular nodular................ 47

5.2 Caracterização do processo de TFD............................................. 47

5.3 Caracterização da população amostral investigada........................ 48

$5.4 \quad$ Caracterização das lesões investigadas....................................... 49

5.5 Relações entre profundidade pré-tratamento do tumor e tamanho e local da lesão.

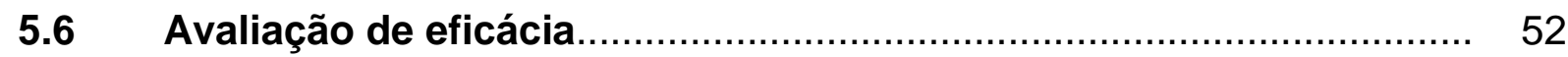

5.7 Relação entre o critério clínico e a análise histopatológica no desfecho do tratamento.............................................................. 54

5.8 Relação de fatores prognósticos e resposta ao tratamento............... 55

5.9 Eventos adversos na terapia fotodinâmica................................ 56

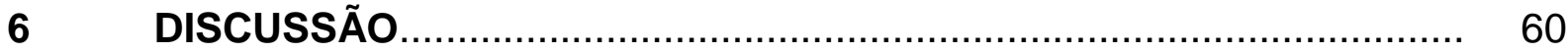

6.1 Aspectos demográficos e das lesões..................................... 60

6.2 Eficácia do tratamento................................................................... 65

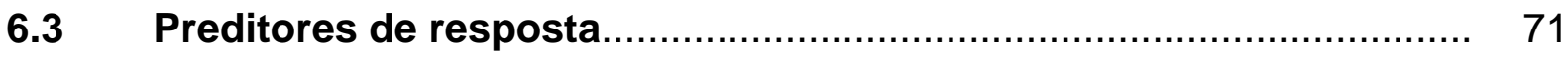

6.4 Efeitos adversos da TFD com Nano-ALA e M-ALA .......................... 72

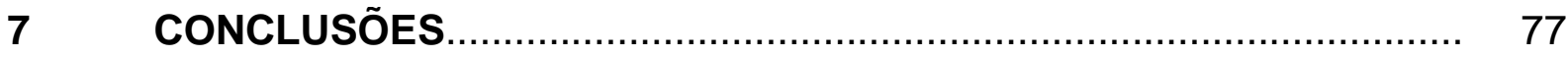

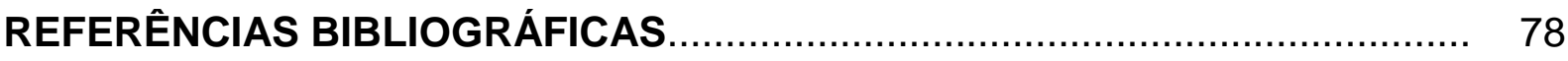
ANEXOS 
As neoplasias malignas de pele, melanoma e não-melanoma, são os tipos de câncer mais comuns na população de cor branca na atualidade. Ambos tumores têm apresentado um aumento de incidência em todo o mundo (CHINEM; MIOT, 2011; INCA, 2014). São esperados, para 2014, 98.420 novos casos de câncer de pele não melanoma nos homens e 83.710 nas mulheres no Brasil. Esses valores correspondem a um risco estimado de 100,75 casos novos a cada 100 mil homens e 82,24 a cada 100 mil mulheres (INCA, 2014).

Entre os cânceres da pele não-melanoma, o carcinoma basocelular (CBC) abrange aproximadamente 70 a $80 \%$ dos casos (INCA, 2014; FANTINI, 2011). O CBC apresenta diversas modalidades clinicas e morfológicas, crescimento lento e afeta predominantemente caucasianos. Enquanto as metástases são extremamente raras, a morbidade resulta da invasão e destruição local, em particular na face, cabeça e pescoço (CHINEM; MIOT, 2011).

Os inquéritos epidemiológicos têm demonstrado que além da crescente incidência de câncer da pele, há aumento da multiplicidade de lesões que podem surgir em um mesmo paciente, assim como a ocorrência de tumores consecutivos. $O$ risco de um paciente com CBC apresentar outra lesão em três anos é de $27 \%$ a 44\%, atingindo até 50\% em cinco anos (CHINEM; MIOT, 2011).

A escolha do tratamento do CBC depende do tipo histológico da neoplasia, da localização, da idade e condições clínicas do paciente, do número de tumores encontrados em um mesmo indivíduo, da disponibilidade de equipamentos da unidade de saúde onde o tratamento será realizado. Além disto, a taxa de cura de cada modalidade terapêutica deve também ser levada em conta para a escolha do tratamento (HACKER; BROWDER; RAMOS-CARO, 1993; R. LINDBERGLARSEN; SØLVSTEN; KRAGBALLE, 2012).

A cirurgia, considerada como a primeira escolha para o tratamento, dependendo do tipo de neoplasia, da sua localização ou da multiplicidade de lesões, pode resultar em grandes áreas mutiladas (HACKER; BROWDER; RAMOS-CARO, 1993. CHINEM; MIOT, 2011). Além disso, a incidência do câncer da pele acentua 
com a idade, sendo mais da metade dos casos na população com idade entre 50 e 80 anos, em que, devido às condições clínicas, a cirurgia tradicional é muitas vezes contraindicada (CHINEM; MIOT, 2011; SOUZA et al, 2011). Assim, é importante a busca de novas modalidades terapêuticas. Entre os tratamentos não cirúrgicos para o carcinoma basocelular (CBC) primário e de baixo risco destacam-se a radioterapia, a quimioterapia tópica e a terapia fotodinâmica (TFD). Por serem modalidades terapêuticas que preservam tecidos, apresentam menos complicações, têm melhores resultados estéticos e, finalmente, não só tratam, mas também melhoram a qualidade da pele: ao exame clinico, observa-se redução da aspereza, do eritema, das telangiectasias e das rugas finas e, na histopatologia, há aumento de colágeno tipo I na derme superior, diminuição da inflamação e do grau e quantidade de atipia celular, minimizando assim a possibilidade de recorrência (TOREZAN, 2011).

A TFD se estabeleceu como terapêutica promissora no tratamento não invasivo do câncer de pele. Essa abordagem terapêutica já é utilizada em fase clínica há mais de 30 anos em vários países (DOUGHERTY; KAUFMANN; GOLDFARB, 1978; KALKA; MELKER; MUKHTAR, 2000; MARMUR, SCHMULTS; GOLDBER, 2004), inclusive no Brasil (DE ROSA et al, 2000; PIERRE et al. 2001a, 2001b; THURCHIELLO et al, 2003; VENA et al, 2004). Atualmente, os tipos histológicos de CBC aprovados para tratamento com terapia fotodinâmica (TFD) são o tipo superficial, sendo inclusive considerado tratamento de escolha por alguns autores (TELFER; COVER; MORTON, 2008), e o tipo nodular, estando esse último restrito a lesões menores, com até $2 \mathrm{~mm}$ de espessura, e em sítio de baixo risco (BRAATHEN et al, 2007).

Os resultados terapêuticos com TFD variam muito. Entre os fatores responsáveis por essas diferenças, os principais estariam relacionados ao medicamento fotossensibilizante usado, como a taxa de absorção cutânea e a subprodução de protoporfirina IX. Para aperfeiçoar os resultados e ampliar o uso clínico da TFD, pesquisas têm sido feitas para aumentar o acúmulo dos medicamentos no tumor, por meio de associação de técnicas como laser fracionado com a TFD, ou trabalhando as formulações e sistemas de carreamento de fármacos usando a nanotecnologia. Muitos desses ainda estão em fase experimental, outros se encontram em fase de estudos clínicos, como o ácido aminolevulínico (ALA) veiculado em uma nanoemulsão lipídico-polimérica na forma de creme (denominada 
Nano-ALA), a qual já foi usada em estudos para tratamento de ceratose actinica, CBC superficial e doença de Bowen, com bons resultados (PASSOS, 2012).

Com o objetivo de avançar no conhecimento da TFD, o presente estudo pretende investigar a eficácia e tolerabilidade do Nano-ALA no tratamento de lesões de carcinoma basocelular tipo nodular com espessura de até $2 \mathrm{~mm}$, comparando os resultados aos do Metil-ALA (M-ALA), atualmente aprovado por agências reguladoras para esse tipo de neoplasia.

\subsection{Justificativa}

CBC é o câncer mais frequente em humanos. A incidência desse tumor maligno aumenta aproximadamente $10 \%$ a cada ano, aumentando os custos dos cuidados com a saúde, tornando-se um problema importante de saúde pública.

O tratamento cirúrgico, embora tenha excelente eficácia para o CBC, pode ser mutilante e ser contraindicado em alguns casos, considerando as condições clínicas do paciente. Portanto, para o tratamento do CBC é útil o aprimoramento de técnicas não invasivas com melhor resultado estético e menores riscos.

Por esse motivo, observa-se uma tendência crescente de utilização de opções não cirúrgicas para tratamentos de CBC de baixo risco. Entretanto, a confirmação prévia do tipo histológico do CBC é fundamental para evitar tratamentos inadequados (WOLBERINK, 2013), pois apenas alguns tipos específicos respondem satisfatoriamente a esses métodos.

A TFD tem seu uso aprovado e estabelecido para tratamento de lesões pré-malignas e para o carcinoma basocelular superficial, tanto com o uso de ALA e de M-ALA. Para o carcinoma basocelular do tipo nodular de até dois $\mathrm{mm}$ de espessura, há aprovação apenas para o M-ALA. Entretanto, deve ser destacado que os resultados clínicos da TFD são variáveis e há as altas taxas de recidiva, observada em estudos com longo período de seguimento (FANTINI et al, 2011). 
Assim, torna-se de grande importância a realização de novas pesquisas, na tentativa de conhecer melhor a eficácia e a tolerabilidade dessas novas tecnologias, assim como superar as limitações atuais no que diz respeito à especificidade pelo tecido alvo, grau de penetração do fármaco e intensidade da dor induzida nos pacientes.

A descoberta de novos fármacos fotossensíveis, assim como de novos sistemas de liberação de medicamentos desenvolvidas pela nanotecnologia, são fundamentais para o aprimoramento da TFD. Nesse contexto, no grupo ligado ao CNANO (UnB), foi desenvolvida uma nova formulação do ALA em concentração padrão de $20 \%$, veiculado em uma nanoemulsão lipídico-polimérica na forma de creme (denominada Nano-ALA), com a intenção de estabilizar o produto, aumentar a sua penetração e seletividade, e assim diminuir o tempo de oclusão necessário para a ação da droga e os efeitos adversos da terapia (PASSOS, 2012).

Já foram conduzidos estudos de terapia fotodinâmica com o Nano-ALA, sendo encontradas excelente eficácia e tolerabilidade para tratamento de ceratose actínica, carcinoma basocelular superficial e doença de Bowen (PASSOS, 2012). Entretanto, ainda não há estudos com o Nano-ALA no CBC nodular, que além de ser o tipo mais freqüente de $\mathrm{CBC}$, é localizado mais comumente em face, onde 0 impacto estético do tratamento cirúrgico pode ser pior.

Por essas considerações, o presente estudo pretende aprofundar 0 conhecimento acerca do uso do Nano-ALA na TFD, estudando a eficácia e tolerabilidade no tratamento do carcinoma basocelular nodular em comparação com o uso do M-ALA. 


\section{OBJETIVOS}

\subsection{Geral}

Estudar a eficácia e tolerabilidade da terapia fotodinâmica no tratamento do carcinoma basocelular do tipo nodular, comparando os efeitos de dois agentes fotossensibilizantes, o ácido aminolevulínico (ALA) veiculado em nanoemulsão (NanoALA) e o metilaminolevulinato (M-ALA).

\subsection{Objetivos específicos}

- Investigar a eficácia da Nano-ALA-TFD em pacientes com lesões de carcinoma basocelular nodular com até $2 \mathrm{~mm}$ de espessura;

- Estudar o perfil de tolerância dos pacientes ao tratamento com Nano-ALATFD e M-ALA-TFD;

- Investigar fatores associados à falha terapêutica;

- Avaliar a acurácia da avaliação clínica como critério de cura em comparação com a avaliação histológica. 


\section{REFERENCIAL TEÓRICO}

\subsection{Carcinoma basocelular}

Foi descrito primariamente por Jacob em 1827, que o denominou ulcus rodens, e sua nomenclatura atual foi proposta por Krompecher em 1903 (apud CHINEM; MIOT, 2011).

Considerado o tipo de câncer mais comum, o tumor apresenta como principais características a indolência e o crescimento lento, requerendo mais de seis meses para atingir o tamanho de um centímetro. Pode ser localmente destrutivo, mas raramente produz metástases (CHINEM; MIOT, 2011; TELFER; COLVER; MORTON, 2008).

As células envolvidas na sua origem são ainda motivo de certa controvérsia. Apesar de se assemelharem às células da camada basal da epiderme, há evidências de se originarem a partir de células pluripotentes imaturas da epiderme interfolicular e as presentes na bainha externa do folículo piloso (CHINEM; MIOT, 2011).

O desenvolvimento de um CBC resulta de alterações genéticas. Por exemplo, mutações no gene PTCH (patched hedgehog), um supressor tumoral localizado nos loci 9q22 (PTCH1) e 1p32 (PTCH2), foram vinculadas ao surgimento de CBC em 30 a 75\% dos casos esporádicos (CHINEM; MIOT, 2011).

O Patched é um receptor para ligantes da família de proteínas hedgehog $(\mathrm{HH})$ e está presente na membrana plasmática das células. A ligação de $\mathrm{HH}$ ao receptor PTCH induz a liberação e ativação de outra proteína localizada na membrana, a smoothened, expressa pelo gene SMO (Figura 1). A ativação de smoothened ativa o fator de transcrição Gli1, o qual induz a transcrição de diversos oncogenes envolvidos no desenvolvimento de CBC e outras neoplasias (CHINEM; MIOT, 2011; SEKULIC, 2012).

Mutações no gene PTCH estimulam a via hedgehog devido à incapacidade da proteína patched na qual houve mutação de suprimir a smoothened (CHINEM; MIOT, 2011; SEKULIC, 2012), conforme mostra a Figura 1. Com base 
nessas alterações moleculares, em 2012 foi aprovado o Vismodegib uma nova droga que age inibindo a proteina SMO para tratamento de CBC avançado (SEKULIC, 2012).

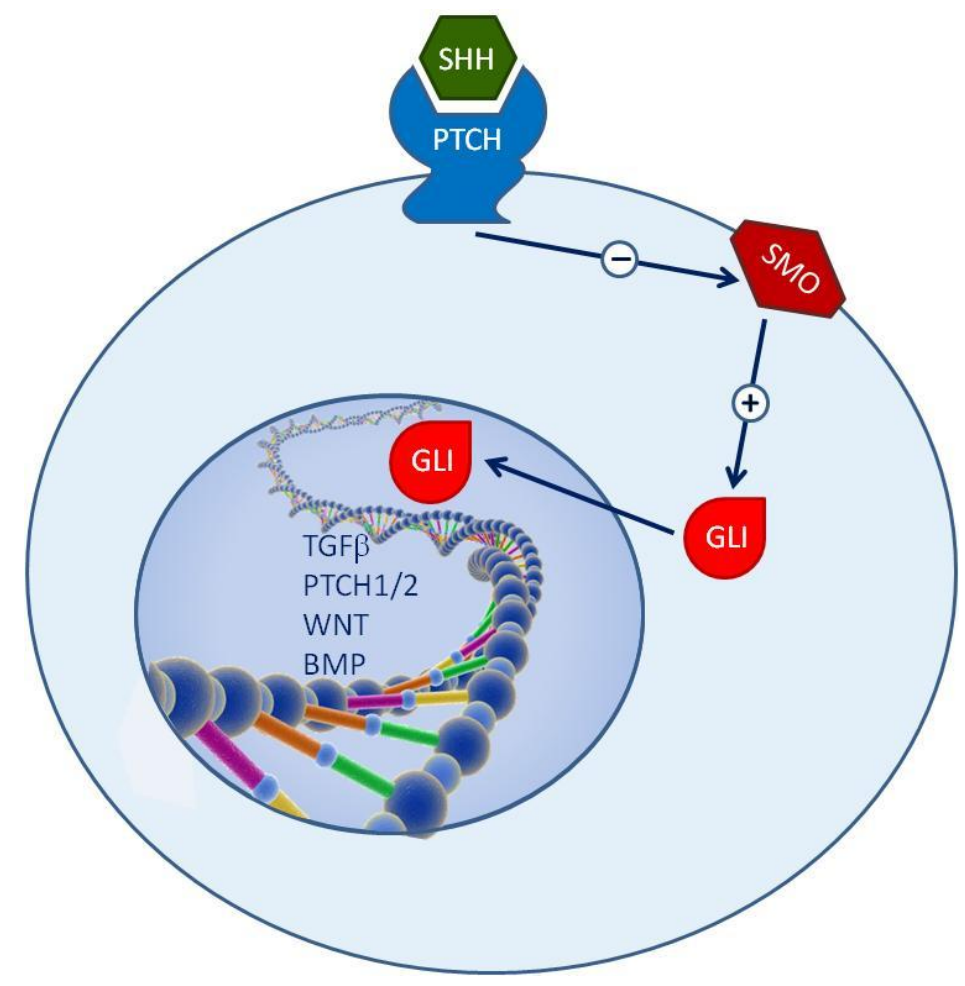

Figura 1 - Esquema representativo de via hedgehog (SHH - proteína sonichedgehog; PTCH - receptor patchedhedgehog; SMO -receptor smoothened; GLI fator GLI-1; TGF $\beta$ - fator transformador de crescimento tipo $\beta$; WNT - via sinalizadora wingless; BMP - proteína morfogenética óssea. Adaptado de CHINEM; MIOT, 2011.

Mutações no gene SMO (smoothened) estão presentes em 10-21\% dos CBCs esporádicos e as mutações no gene p53 em mais de $50 \%$ dos casos. Entretanto, as mutações de p53 parecem estar mais relacionadas à progressão do que à gênese do CBC (CHINEM; MIOT, 2011).

Em contraste com os genes de supressão tumoral (PTCH, P53), os oncogenes desempenham papel menor no desenvolvimento desse tumor (PONTÉN; LUNDBERG; ASPLUND, 2011). Não estão elucidados os padrões de expressão genética que levam às diversidades fenotípicas de formas clínicas, subtipos histopatológicos e comportamento biológico dos CBC (CHINEM; MIOT, 2011). 
Radiação solar, em particular a radiação ultravioleta (RUV), é considerada a principal causa ambiental para formar CBC. Algumas pesquisas indicam provável correlação entre o perfil de exposição solar e o tipo histológico: por exemplo, CBC nodular e exposição crônica ao sol, enquanto padrões intermitentes e agudos de exposição se relacionam com CBC superficial (CHINEM; MIOT, 2011).

A ação da RUV pode se dar por meio de efeito direto e indireto. $O$ efeito direto no DNA produz mutação de transição com formação de dímeros ciclobutano-pirimidina e fotoprodutos pirimidina-pirimidina (PONTÉN; LUNDBERG; ASPLUND, 2011; TOREZAN, 2011). Por outro lado, o dano celular indireto ocorre por processo de fotossensibilização, isto é, reação fotoquímica que ocorre quando as moléculas do cromóforo, que não é DNA, absorvem os fótons e se excitam chegando ao estado tripleto e, ao voltarem ao estado inicial, geram um processo que implica em reações intracelulares de transferência da energia recebida.

Esse processo por sua vez, pode ocorrer por duas vias principais chamadas de reações fotossensibilizadas Tipo I e II. Na reação Tipo I ocorre transferência direta de um elétron entre o cromóforo excitado e outra molécula, e a energia pode se transferida ao DNA; na reação Tipo II, ocorre transferência de energia do cromóforo para o oxigênio molecular, acarretando a formação de radicais reativos de oxigênio, como oxigênio singleto e superóxido. A ação dos radicais livres resultantes dessas reações leva por sua vez dano ao DNA (TOREZAN, 2011).

Os riscos individuais para desenvolver o câncer de pele são determinados não só por grande deficiência de reparo do dano ao DNA através do NER (via de excisão de nucleotídeos), mas também por variações mais sutis na eficiência de reparo, como acontece com a idade (PONTÉN; LUNDBERG; ASPLUND, 2011).

Destaque-se que a RUV pode levar a um grau de imunossupressão pela depleção de células dendríticas e da expressão alterada de citocinas, o que resulta no desvio da resposta imune celular para Th2 e inibe a habilidade das células apresentadoras de antígeno em induzir atividade antitumoral, o que pode ser relevante na progressão do tumor (CHINEM; MIOT, 2011). 
O CBC possui diferenças de comportamento biológico em relação a outros tumores que podem ser explicadas pela presença de fatores intrínsecos ao próprio tumor, como padrão de crescimento tumoral, potencial de recorrência e de metástase, padrão histológico e fatores genéticos, assim como por fatores extrínsecos, como sítio de origem, terapêutica escolhida e o estado imunológico do portador da neoplasia (CABRERA et al, 1992; CHINEM; MIOT, 2011).

Do ponto de vista histológico, a classificação baseada nos padrões de crescimento tem maior significância biológica e considera a existência dos tipos nodular, superficial, infiltrativo, esclerodermiforme, micronodular e de padrão misto (SALDANHA; FLETCHER; SLATER, 2003). A identificação desses padrões é útil na conceituação de alto e baixo risco dos subtipos histológicos de CBC (LEBOIT et al, 2006).

Outros fatores prognósticos que devem ser levados em consideração para classificação do CBC em baixo ou alto risco de recidiva são o tamanho e local da lesão, e o nível da invasão, conforme apresentado na tabela 1. Esses fatores são determinantes na escolha terapêutica e no sucesso do tratamento, sobretudo quando se trata de modalidades não cirúrgicas (TELFER; COLVER; MORTON, 2008). 
Tabela 1 - Critérios de risco e classificação do carcinoma basocelular nodular.

\begin{tabular}{|c|c|c|}
\hline Critérios de risco & Baixo risco & Alto risco \\
\hline \multirow{3}{*}{$\begin{array}{l}\text { Localização e } \\
\text { tamanho }\end{array}$} & $\begin{array}{c}\text { Área central da face, } \\
\text { periorbitalperiauricular }< \\
6 \mathrm{~mm}\end{array}$ & $\begin{array}{c}\text { Área central da face, periorbital, } \\
\text { periauricular }>6 \mathrm{~mm} .\end{array}$ \\
\hline & $\begin{array}{l}\text { Bochecha, testa, } \\
\text { pescoço, couro } \\
\text { cabeludo }<10 \mathrm{~mm}\end{array}$ & $\begin{array}{l}\text { Bochecha, fronte, pescoço, couro } \\
\text { cabeludo }>10 \mathrm{~mm} \text {. }\end{array}$ \\
\hline & $\begin{array}{c}\text { Tronco e extremidades } \\
<20 \mathrm{~mm}\end{array}$ & Tronco e extremidades $>20 \mathrm{~mm}$ \\
\hline Bordas e crescimento & Bordas bem definidas & Bordas mal definidas \\
\hline Subtipo histológico & Nodular e superficial & $\begin{array}{l}\text { Esclerodermiforme, Micro nodular } \\
\text { Multicêntrico, Basoescamoso, } \\
\text { Infiltrativo. }\end{array}$ \\
\hline $\begin{array}{l}\text { Envolvimento } \\
\text { perineural }\end{array}$ & Não & Sim \\
\hline $\begin{array}{l}\text { CBC primário } \times \\
\text { Recidiva }\end{array}$ & Primário & Recidivante; Excisão incompleta. \\
\hline Imunossupressão & Não & Sim \\
\hline
\end{tabular}


A figura 2 ilustra as localizações de alto risco.
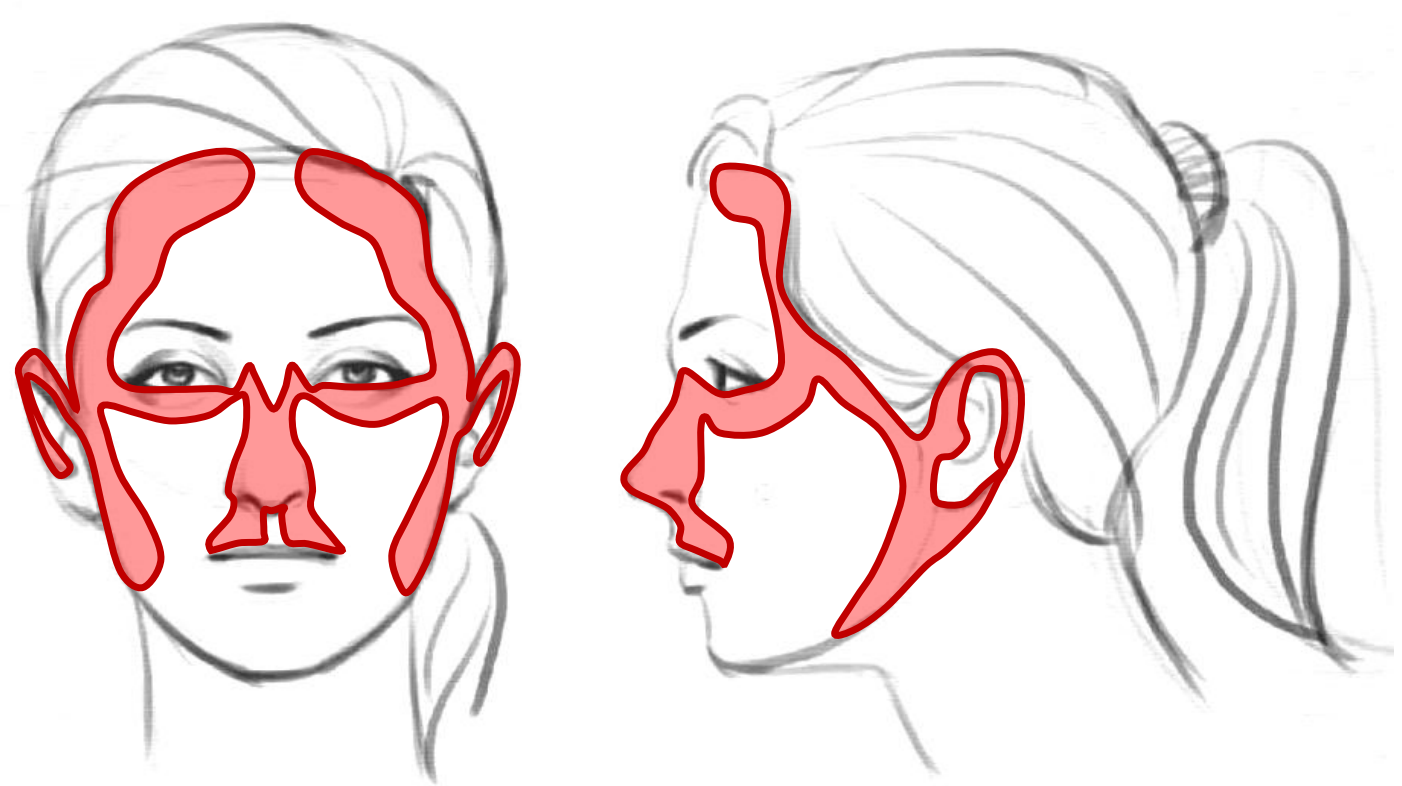

Figura 2 - Áreas de alto risco para recidivas na face representada pela cor vermelha da face (área "H"). Adaptado de MOSTERD et al, 2008. Imagem de fundo obtida em www.symbiosysart.com.

A realização da biopsia para exame histopatológico é indispensável para identificar os subtipos histológicos, classificar o tumor e planejar a abordagem terapêutica adequada. Contudo, a precisão do diagnóstico feita por biopsia com punch de CBC primário e a prevalência do subdignóstico de subtipos agressivos nessas amostras podem variar. Estudos prévios mostraram taxas de discordância variando entre $18 \%$ e $49 \%$ com relação ao subtipo de CBC, quando se compara biopsia por punch e shaving com excisão (IZIKSON; SEYLER; ZEITOUNI, 2010; WOLBERINK, 2012).

Cerca de $40 \%$ de todos os CBC são do tipo misto, ou seja, são constituídos por vários tipos de CBC em uma só lesão. A avaliação histológica de uma só parte do tumor misto levaria, consequentemente, a erro de diagnóstico e se o subtipo não detectado for o mais agressivo pode resultar em falha terapêutica (IZIKSON; SEYLER; ZEITOUNI, 2010; WOLBERINK, 2012). 
O padrão ouro para estabelecer o subtipo histológico final do CBC é a excisão. No entanto, apesar das limitações citadas previamente, a determinação do subtipo por biopsia se torna relevante por causa do uso crescente de tratamentos não cirúrgicos, como a TFD ou aplicação tópica de imiquimode para os casos menos agressivos.

A busca da classificação ideal do CBC que ligaria o subtipo ao seu comportamento biológico, tem sido ampliada devido aos avanços das pesquisas nas áreas da genética e da biologia molecular relacionada à fisiopatologia do câncer. Assim, o uso de imunohistoquímica pode levar à identificação dos tipos agressivos e formar novas estratégias para desenvolvimento de tratamentos mais eficazes (SALDANHA; FLETCHER; SLATER, 2003; CIUREA et al, 2013).

Entre os marcadores estudados, se encontram os de expressão próapoptótica TP53 e bcl-2, que tendem a identificar a agressividade do CBC (MATEOIU; PIRICI; BOGDAN, 2011). Outros marcadores de agressividade são: (1) a metalopeptidase de matriz, a MMP-13, que provoca a degradação da matriz extracelular; (2) a molécula de adesão celular $\beta$-catenina e o complexo receptorligante de quimiocinas, o CXCR4, cuja interação leva a mudanças das propriedades de adesão entre as células tumorais e progressão do tumor. Esses marcadores possuem reatividade variada entre os tipos histológicos de CBC. No entanto, a reação mais intensa é encontrada em subtipos mais agressivos como o metaplásico, principalmente nas bordas invasivas da lesão (CIUREA et al, 2013).

O carcinoma basocelular nodular, considerado um subtipo histológico de baixo risco, é o subtipo mais frequente, sendo responsável por 60 a $80 \%$ dos tumores da face. O CBC nodular ocorre mais comumente em pacientes com idade mais avançada e compromete principalmente o rosto e o pescoço, diferentemente do CBC superficial que ocorre em pacientes mais jovens e no tronco. Na face, 20 a $30 \%$ dos casos de CBC nodular se localizam no nariz. Outras regiões frequentes são as pré auriculares, malares e fronte (LEBOIT et al, 2006).

O CBCn se apresenta clinicamente como pápula rosada com telangiectasias na periferia e borda perolada, podendo mostrar alguns pontos de pigmento marrom constituindo a variante CBC pigmentado (PONTÉN; LUNDBERG; 
ASPLUND, 2011). É normalmente assintomático e o sangramento é a única queixa relatada (CHINEM; MIOT, 2011).

Os CBCs nodulares evoluem com ulceração do centro ou tornam-se císticos, podendo atingir grande dimensão e alargar profundamente (PONTÉN; LUNDBERG; ASPLUND, 2011). A histopatologia do CBC nodular é caracterizada por grandes lóbulos de células basalóides bem circunscritos e projetados na derme reticular ou mais profundamente; os lóbulos podem estar associados à degeneração mucinosa com cistos ou apresentar um padrão adenóide. Alguns nódulos podem ser encontrados junto aos pequenos lóbulos basalóides e estar ligados a um estroma fibromucinoso frouxo, caso em que a periferia da lesão deve ser rastreada para afastar o subtipo micronodular(LEBOIT et al, 2006).

As opções de tratamentos tópicos e não cirúrgicos para CBC de baixo risco têm surgido como modalidades eficazes, ficando a cirurgia como método de escolha para os casos de alto risco (BATH-HEXTALL, et al, 2007).

\subsection{Terapia fotodinâmica}

A terapia fotodinâmica (TFD) é definida como uma reação fotoquímica utilizada com o objetivo de causar destruição seletiva de um tecido. Consiste em uma técnica terapêutica de duas etapas, sendo que na primeira se utiliza um fármaco fotossensibilizante tópico que deve ser ocluído por um determinado período de tempo e, em uma segunda etapa, é feita irradiação da lesão com luz visível de comprimento de onda determinado (ISSA; AZULAY, 2010).

A TFD teve origem no inicio do século $X X$, em Munique/Alemanha, quando Oscar Raab e seu professor Herman von Tappeiner observaram os efeitos decorrentes da fotossensibilização em paramécios. Raab observou a morte rápida de protozoários Parameciumcaudatum depois de exposição à luz na presença do corante acridina. A presença da luz modificando a ação do corante permitiu a identificação de um agente fotossensibilizante (REGO, 2008; ISSA; AZULAY, 2010).

O uso clínico da TFD foi feito pela primeira vez por Dougherty e colaboradores (1978), com relato de sucesso no tratamento de câncer cutâneo e de 
outras malignidades. Em 1990, Kennedy, Pottier e Pross introduziram o uso do ácido 5-aminolevulínico (ALA) na TFD de doenças cutâneas. Desde então, o uso tópico representa uma das técnicas mais populares de TFD em dermatologia, especialmente devido à vantagem de não apresentar fotossensibilidade cutânea generalizada (KALKA; MERK; MUKHTAR, 2000; MARMUR; SCHMULTS; GOLDBERG, 2004).

Na literatura científica, é encontrada uma série de estudos que busca compreender os mecanismos de ação da TFD em nível molecular, celular e tecidual (CASTANO; DEMIDOVA; MICHAEL, 2005a E 2005b). O conhecimento da ação da luz no agente fotossensível e as reações decorrentes são essenciais para o aprimoramento da TFD.

No local da aplicação, por meio de uma série de reações bioquímicas celulares, o pró-fármaco (ALA) é enzimaticamente convertido em um fármaco fotossensível endógeno ativo, a protoporfirina IX (PpIX), que sensibiliza as células neoplásicas à ação da luz em comprimento de onda específico, desencadeando um processo de morte celular (KENNEDY; POTTIER; PROSS, 1990; KENNEDY; POTTIER, 1992).

A morte celular induzida após aplicação da TFD pode ocorrer por dois modos distintos, a necrose e a apoptose. Esses dois modos podem ocorrer de forma isolada ou concomitante, influenciados por vários fatores como tipo e localização do fotossensibilizante (FS). Evidências sugerem que a presença do FS na mitocôndria induz a apoptose e, quando localizado na membrana plasmática ou em lisossomos, conduz à necrose. Outros fatores envolvidos no processo de morte celular são a quantidade de oxigênio gerado, tipo e dose da luz (CASTANO; DEMIDOVA; MICHAEL, 2005a; LOVELL et al, 2010).

$\mathrm{Na}$ fase de iluminação da TFD, o agente fotossensibilizante presente nas células tumorais é ativado e absorve fótons. Esta ativação o leva do estado de repouso ao estado de ativação, gerando o estado singleto, de meia vida curta. Nessa etapa, as moléculas podem retornar ao estado de repouso, emitindo energia em forma de fluorescência por meio da liberação de fótons ou progredir na cadeia de reações químicas, até atingir o estado tripleto de meia vida mais longa. 
As moléculas no estado tripleto podem sofrer dois tipos de reação. $\mathrm{Na}$ reação tipo I, ocorre transferência de elétrons para receptores moleculares e formação de radicais livres, como os radicais superóxido, hidroxila e peróxido. Já na reação tipo II, predominante na TFD, as moléculas transferem sua energia diretamente ao oxigênio intracelular, formando o oxigênio singleto $\left({ }^{1} \mathrm{O}_{2}\right)$, altamente reativo, de meia vida muito curta e responsável pela morte celular por interagir com componentes como lipídios, ácidos nucleicos e aminoácidos (TOREZAN, 2011; LOVELL et al, 2010).

A resposta imune induzida pela TFD constitui o segundo efeito antitumoral dessa terapia, Ao contrário do que se pensava inicialmente, que a importância da resposta do sistema imunitário à TFD limitava-se à recuperação da homeostase local e ao processo de cicatrização, a ativação imune desempenha um papel importante na resposta terapêutica (KORBELIK; SUN, 2006).

Os efeitos provocados por lesão fototóxica, como alterações da membrana plasmática e da membrana das organelas, que não são necessariamente letais para todas as células tumorais, estimulam a liberação ou expressão de vários mediadores de resposta aguda pró-inflamatória, os quais incluem proteínas do complemento, proteínas de choque térmico (HSP), derivados de ácido araquidônico, quimiocinas e citocinas, como o fator de necrose tumoral alfa (TNF- $\square$ ), interleucina 6 (IL-6) e interleucina 1 (IL-1) (HADJUR et al, 1996). Ocorre também acúmulo de neutrófilos e estímulo à destruição tumoral (AGOSTINIS et al, 2011).

O complemento não só atua como mediador, mas também estimula as células a liberarem mediadores secundários incluindo as citocinas IL-1, TNF-alfa, IL6, IL-10, fator estimulante de colônias de granulócitos (TGF-G), prostaglandinas, leucotrienos, histamina e fatores de coagulação. Macrófagos e neutrófilos podem mostrar citoxicidade preferencial contra células tumorais tratadas com dose sub-letal de TFD e, em consequência, grande impacto na resposta (AGOSTINIS et al, 2011; CASTANO; DEMIDOVA; MICHAEL, 2005).

As atividades de elementos da imunidade inata culminam na orquestração do desenvolvimento da resposta imune adquirida com base no reconhecimento de antígenos de tumores tratados com TFD, levando à ideia de 
explorar esse mecanismo para geração de vacina antitumoral (KORBELIK; SUN, 2006).

O terceiro mecanismo antitumoral dessa terapia se faz em nível vascular. O dano ao endotélio acarreta quebra da função de barreira da parede do vaso, perda da junção entre as células endoteliais, exposição da membrana basal vascular com consequente ativação de plaquetas e de polimorfonucleares neutrófilos. Essa sucessão de eventos leva à vasoconstrição das arteríolas e formação de trombos venosos e, subsequentemente, à hipóxia e necrose tecidual. Assim, a necrose isquêmica parece ser o principal mecanismo de destruição do tumor submetido à TFD com agentes sistêmicos, enquanto, com agentes tópicos (ALA e M-ALA), a citotoxicidade é decorrente da ação do ${ }^{1} \mathrm{O}_{2}$ (TOREZAN, 2011; LOVELL et al, 2010).

Entre os efeitos colaterais da TFD, destaca-se a dor relacionada ao tratamento. Essa varia de intensidade e pode ser descrita como queimação, sensação de ardência ou prurido restrita à área tratada. Começa minutos após o início da irradiação e se mantém por algumas horas. O mecanismo da dor provavelmente envolve a estimulação nervosa através de receptores localizados em terminações de fibras mielinizadas do tipo delta $A$ e não-mielinizadas do tipo $C$ do nervo, e/ou dano tecidual sofrida pelo substâncias citotóxicas e/ou inflamação criadas na reação fotodinâmica e agravadas pela hipertermia (CHAVES et al, 2012; MORTON et al, 2013).

A intensidade da dor pode estar relacionada ao agente utilizado, sendo que alguns estudos mostraram que M-ALA-TFD era menos doloroso do que ALATFD (BABILAS et al, 2010). A dor aumenta quando a lesão a ser tratada localiza em áreas mais inervadas como segmento cefálico e mãos; em lesões ou áreas mais extensas; com aumento das fluências e irradiâncias; na segunda sessão; com a fluorescência; e em fototipos mais claros. Maiores níveis de dor também foram registrados quando se trata de ceratoses actínicas em relação ao observado com CBC e doença de Bowen (BABILAS et al 2010; MORTON et al, 2012; CHAVES et al 2012).

O alívio da dor pode ser obtido principalmente com aplicação de ar frio e com o uso de analgésico via oral. O uso dos anestésicos tópicos, por outro lado, 
se mostra ineficaz. Uma possível explicação para o fracasso dos anestésicos tópicos na TFD é o fato de tanto o ALA quanto o M-ALA terem $\mathrm{pH}$ ácido, enquanto a maioria dos anestésicos tópicos tem $\mathrm{pH}$ alcalino, promovendo uma interação medicamentosa que prejudica a eficácia (BABILAS et al 2010; CHAVES et al 2012). Ao contrário o uso de anestesia tanto infiltrativa quanto o bloqueio de ramos mostram ser eficazes no alívio da dor. Recomenda-se, entretanto, sempre utilizar anestésicos sem vasoconstritor, a fim de permitir o aporte adequado de oxigênio na área a ser tratada, garantindo a eficácia da TFD (CHAVES et al 2012).

Eritema e edema no local são encontrados em um grande número de casos (cerca de 90\%), podendo persistir por uma semana e evoluir com formação de crostas e descamação. Raramente há formação de úlceras. Pústulas, normalmente estéreis, podem se formar em 6\% dos casos (BABILAS 2010).

Em geral, a recuperação se dá em duas semanas a três semanas (FELÍCIO et al, 2008; ISSA; AZULAY, 2010). Alterações pigmentares são raras e transitórias, assim como a alopecia local (BABILAS et al, 2010).

A TFD tem seu uso liberado pelos órgãos responsáveis, tanto no Brasil (ANVISA) como em outros países, para tratamento de lesões pré-neoplásicas e tumores não-melanoma bem delimitados e superficiais (CBC superficiais e doença de Bowen). Possui várias vantagens em relação a outras modalidades de tratamentos, como cirurgia, quimioterapia e radioterapia (DOUGHERTY et al, 1998; FELÍCIO et al, 2008). As conveniências incluem o fato de ser uma técnica minimante invasiva e específica; pode ser repetida várias vezes sem acarretar problemas para o paciente como doses máximas tóxicas ou criar resistência; tem potencial para ativar o sistema imunitário e controlar o tumor, até mesmo em eventuais sítios metastáticos (CASTANO; DEMIDOVA; MICHAEL, 2005b); e, adicionalmente, é uma alternativa em pacientes com dificuldade, impossibilidade, alto risco ou recusa do procedimento cirúrgico. Devem ainda ser consideradas as vantagens decorrentes da possibilidade de tratamento ambulatorial, o tratamento de lesões múltiplas em sessão única e, por fim, os resultados estéticos superiores.

Entretanto, algumas restrições da TFD devem ser consideradas: 0 período de oclusão; a dor; e a recorrência crescente em período prolongado de observação com sessão única de TFD-ALA. Esta recorrência, entretanto, pode ser 
reduzida com a repetição dos tratamentos (FELíClO et al, 2008). Por fim, destaca-se a principal limitação do método, que é o fato da TFD ser restrita ao tratamento de tumores superficiais, locais e não invasivos devido à limitação de absorção do fármaco e da luz em tecidos mais profundos (REGO, 2008).

A eficácia da TFD depende da distribuição do fotossensibilizante no tecido alvo, ou seja, na lesão. Essa distribuição depende da permeabilidade do agente no estrato córneo, difusão através da epiderme e derme e da liberação e produção do PpIX. Teoricamente existem três vias potenciais de passagem de um medicamento na pele: a transcelular, a intercelular e a transfolicular, como mostrado na Figura 3.

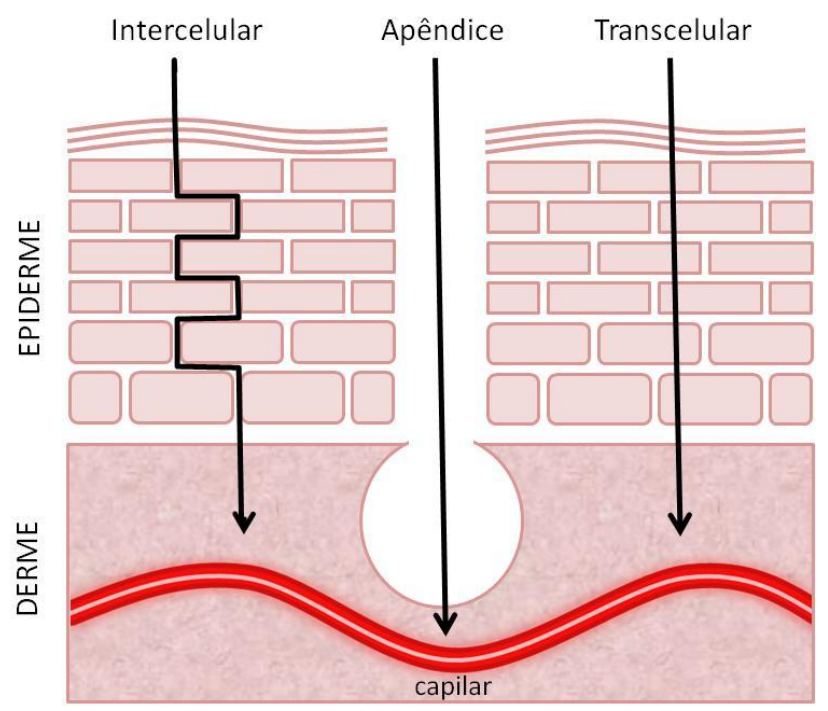

Figura 3 - Representação esquemática dos mecanismos de penetração percutânea de fármacos (adaptado de BARRY, 2004).

A epiderme é camada superior da pele, cuja espessura apresenta variações de 0,04 $\mathrm{mm}$ nas pálpebras até $1,6 \mathrm{~mm}$ nas regiões palmares e plantares. Ela é constituída por um epitélio estratificado que por sua vez é dividido em camadas. A mais profunda é a camada basal, seguida pela malpighiana ou espinhosa, pela camada granulosa e, mais superficialmente, há a camada córnea ou extrato córneo.

A derme encontra-se logo abaixo da epiderme e compreende denso estroma fibroelástico no qual se situam as estruturas vasculares, nervosas e os anexos como as glândulas sudoríparas e sebáceas e folículos pilosos. 
A camada córnea é a principal barreira para passagem de substâncias externas através da pele, o que acontece devido à sua estrutura peculiar de ceratinócitos e lipidios. Os ceratinócitos são células epidérmicas anucleadas, com membranas citoplasmáticas espessas, cujo citoplasma corresponde a um sistema bifásico de filamentos de ceratina encerradas em uma matriz amorfa composta de filagrina. As membranas plasmáticas das células adjacentes são separadas por um espaço intercelular (SAMPAIO; RIVITTI, 2001), que contém glicoproteínas e lipídios. Os lipídios são compostos de ceramidas, colesterol, ácidos graxos livres, dispostos em estruturas de folhas de bicamada. Os lipídios que preenchem o espaço intercelular formam a camada hidrofóbica responsável pela função de barreira, impedindo assim a perda de água e progressão de substâncias hidrofílicas (PIERRE et al, 2001b).

Do ponto de vista de penetração, a pele pode ser considerada como barreira mecânica nanoporosa, com poros hidrofílicos e diâmetro variando de 0,4 a $36 \mathrm{~nm}$, por onde as moléculas com capacidade de penetração atravessam a pele (BERTOLINI, 2009). Entre as características cutâneas que influenciam a permeação encontram-se a espessura da camada córnea, a concentração dos folículos pilosos e os arranjos das camadas lipofílicas e hidrofílicas (CHORILLI et al, 2007; (BERTOLINI, 2009).

O transporte de fármacos pela pele é complexo, devido às propriedades estruturais distintas de ambos. Podem ser destacados três fatores que influenciam a penetração percutânea: (1) As propriedades físico-químicas da molécula do medicamento penetrante; (2) o sistema de liberação do fármaco; (3) a combinação entre pele, fármaco e sistema (BERTOLINI, 2009). Assim, alterações nas propriedades físico-químicas do fármaco, na sua formulação ou no sistema de liberação podem facilitar a permeação do ativo de interesse consequentemente, 0 sucesso da TFD (GERRITSEN et al, 2008).

Várias estratégias estão sendo levadas em conta para vencer a limitação da penetração do fotossensibilizante e a absorção e seu metabolismo dentro da pele, começando com as técnicas para diminuição da barreira do estrato córneo, o que pode ser feita com creme esfoliante, curetagem leve e 
microdermoabrasão. Nos casos de carcinoma basocelular nodular tem se tentado também o shaving e eletrocirurgia prévia (GERRITSEN et al, 2008).

Entre os promotores físicos de penetração tem-se: (1) o uso de iontoforese; (2) o aumento da temperatura da pele no início do tratamento, com resultados variáveis; (2) sonoferese, com pré-aplicação de ultrassom de baixa frequência, o que mostra significante aumento da penetração e retenção do ALA na pele comparado com a penetração passiva (KRISHNAN et al, 2013); (3) o uso de laser ablativo (LEE et al, 2010) e de microagulhas (TOREZAN et al, 2013) e (4) o desenvolvimento de ALA e M-ALA em forma de sistemas de adesivos transdérmicos, que têm a vantagem de ter a mesma quantidade do medicamento, mostrando bons resultados (BABILAS et al, 2010). O desenvolvimento de novos derivados do próprio ALA a fim de torná-lo mais lipofílico e assim aumentar a sua penetração foi estimulado e assim, foi desenvolvido o metil-ALA, representado como M-ALA, nome comercial Metvix®, já em uso clínico, e posteriormente o hexyl-ALA (H-ALA) que mostra-se promissor (MORROW et al, 2010).

Os promotores de absorção são substâncias químicas usadas como excipientes com a finalidade de aumentar a absorção de medicamentos tópicos, que agem alternando a composição e ou organizando as camadas lipídicas e proteicas do extrato córneo, diminuindo assim sua função de barreira. Atuam nos caminhos polares e/ ou apolares do extrato córneo, modificando a polaridade dos lipídios ou das proteínas e, consequentemente, interferindo na estrutura rígida dos lipídios da matriz, aumentando a fluidez. Podem também desnaturar as proteínas dos ceratinócitos, diminuindo seu grau de compactação (BERTOLINI, 2009).

E, por fim, há os chamados sistemas de entrega mais seletivos, especialmente os que empregam estratégias da nanobiotecnologia, como o ALA em veículo nanoestruturado, o Nano-ALA. Estas nanoestruturas visam especificidade e aumento da penetração do pró-fármaco e assim melhoria dos resultados obtidos com a TFD (YANG et al, 2009).

Para aumentar a eficácia do tratamento com a TFD, além das pesquisas que têm sido feitas no sentido de aumentar tanto a penetração dos medicamentos como a produção do PpIX, têm sido desenvolvidas fontes de luz mais especificas e de baixo custo, assim como novos protocolos clínicos. 


\subsection{Fármacos fotossensibilizantes}

Fotossensibilizantes são compostos que absorvem a energia luminosa em um comprimento de onda específico e tornam-se excitados, provocando uma reação química com o oxigênio molecular (WACHOWSKA et al, 2011).

Existem dois tipos de fotossensibilizantes, os quais são ou não derivados de porfirina. Por sua vez, os fotossensibilizantes da família porfirina se classificam em três gerações: os de primeira geração são derivados de hematoporfirina de uso sistêmico e, apesar de eficientes em quase todos os tipos de tumores, apresentam reação cutânea de fotossensibilidade por período prolongado, ou seja, durante todo o tempo necessário para a eliminação do fármaco pelo organismo (REGO, 2008; WACHOWSKA et al, 2011).

O ALA e seus derivados são considerados de segunda geração e seu principal diferencial é superar a fotossensibilidade prolongada, enquanto os fotossensibilizantes de terceira geração são os agentes fotossensibilizantes acoplados ao anticorpo ou qualquer outra moléculas alvo (WACHOWSKA et al, 2011).

Em 1990, Kennedy, Pottier e Pross revolucionaram a TFD com uma técnica simples baseada na aplicação de uma substância tópica, o ácido 5-delta aminolevulínico (ALA). O ALA é um precursor da protoporfirina IX (PpIX) que é sintetizada no interior das células por meio da biossíntese do grupo Heme. A PpIX é o intermediário porfirínico com atividade fotodinâmica e, quando ativado por luz azul, emite fluorescência vermelha intensa (REGO, 2008; TOREZAN, 2009a).

As características ideais de um fotossensibilizante para a TFD são a pureza química, a capacidade de localização específica em tecido neoplásico, o intervalo pequeno entre a administração do fármaco e o acúmulo máximo no tumor, a meia-vida curta, a eliminação rápida do tecido normal, a ativação por comprimentos de onda com ótima penetração no tecido alvo e a capacidade de produzir grande quantidade de produtos citotóxicos (KALKA; MERK; MUKHTAR, 2000; FELíCIO et al, 2008).

O ALA é um composto hidrofílico em pH fisiológico, por isso possui capacidade limitada de atravessar as barreiras biológicas hidrofóbicas da pele, como 
membranas celulares e extrato córneo. Essa penetração é uma condição fundamental para conversão do ALA em PpIX (KLOEK; AKKERMANS; VAN HENEGOUWEN, 1998). Em células de mamíferos, o ALA é carreado principalmente por mecanismos de transporte ativo que requerem energia. Esses sistemas são lentos, mas encontram-se levemente acelerados em células tumorais (RUD et al, 2000, GAULLIER,1997). Os melhores resultados terapêuticos são obtidos com concentrações entre 10\% e 20\% (MORTON et al, 2002). O uso do ALA tópico tem aprovação pelo FDA (Food and Drug Administration/USA) para tratamento de ceratose actinica desde 1999. A taxa de transporte do ALA através da membrana plasmática é o único limite para o acúmulo de porfirinas fluorescentes nas células tratadas.

$\mathrm{Na}$ tentativa de minimizar muitos dos problemas encontrados na aplicação tópica do ALA, como descrito acima, foram desenvolvidos fármacos mais lipofílicos derivado do ALA, como o metilaminolevulinato ou M-ALA (GEDERAAS et al,2001). O M-ALA é um derivado esterificado do ALA, é lipofílico e apresenta maior seletividade para células neoplásicas quando comparado ao ALA. Em geral, os agentes sensibilizantes lipofílicos são captados pela célula por penetrarem diretamente pela membrana plasmática, e essa captação aumenta em proporção direta com a hidrofobicidade da molécula, enquanto as moléculas hidrossolúveis são captadas por pinocitose (CALZAVARA-PINTON; VENTURINI; SALA, 2007).

Um maior grau de hidrofobicidade pode aumentar a eficácia por promover altos níveis de fototoxicidade induzida por PpIX (MORTON et al, 2002). O M-ALA é transportado por mecanismo ativo e também por difusão passiva pela membrana. O mecanismo passivo não requer energia e não é saturável, sendo eficiente principalmente nas células neoplásicas (TOREZAN; NIWA; NETO, 2009b). A maior seletividade para células tumorais, detectada por fluorescência da Pp IX, pode ser favorecida pela melhor penetração através das membranas celulares quando comparado ao ALA.

Até o momento, não são bem esclarecidos os mecanismos pelos quais ocorre a retenção seletiva dos fotossensibilizantes nos tecidos malignos. Algumas hipóteses incluem a permeabilidade alterada da membrana celular, o aumento do número e da permeabilidade dos vasos sanguíneos, bem como a drenagem linfática 
diminuída. Além disso, o pH baixo no fluido intersticial nos tumores facilita a biodistribuição seletiva dos fotossensibilizantes (TOREZAN; NIWA; NETO, 2009b).

Logo após a penetração, o M-ALA é demetilado em ALA, e as etapas metabólicas subsequentes até a produção da PpIX intramitocondrial são as mesmas (KALKA; MERK; MUKHTAR, 2000; CALZAVARA-PINTON; VENTURINI; SALA, 2007). O M-ALA é aprovado para tratamento de ceratose actínica, bem como para tratamento de CBC superficial e nodular. Em 2009, o M-ALA foi aprovado para tratamento da doença de Bowen também no Brasil. A TFD com M-ALA e luz vermelha tem protocolo de técnica de aplicação bem estabelecido.

Uma das vantagens do uso tanto do ALA quanto do M-ALA é que são rapidamente degradados pelo organismo, eliminando em poucas horas possíveis riscos da fotossensibilização do tecido (WEBBER; KESSEL; FROMM, 1997). Além disso, são quimicamente puros, absorvem luz próxima ou acima de $650 \mathrm{~nm}$ e, em função das baixas doses administradas, os efeitos colaterais tendem a ser pouco ou nada pronunciados (CALZAVARA-PINTON; VENTURINI; SALA, 2007). No entanto, o M-ALA possui uma tendência a apresentar melhor resposta fotodinâmica do que o $A L A$, principalmente devido às diferenças entre as formulações dos medicamentos (REGO, 2008). Atualmente, novas pesquisas para avaliar a melhoria da penetração do ALA têm sido feitas com base na nanobiotecnologia, especialmente no que se refere a veículos em nanoemulsão.

\subsection{Nanobiotecnologia}

A nanotecnologia é uma ciência multidisciplinar que tem avançado rapidamente nos últimos anos, encontrando aplicações nas mais diversas áreas, desde setores da eletrônica até a indústria farmacêutica (CATTANEO et al, 2010).

Os materiais em nanoescala apresentam características físicas, químicas, ópticas, eletrônicas, mecânicas e térmicas diferentes das do seu material de origem ou bulk (DELOUISE, 2012), na maioria das vezes advindas do aumento da área de superfície em relação ao seu volume (NEL et al, 2006). 
Nanobiotecnologia e nanomedicina são ramos da nanotecnologia que exploram essa ciência e suas aplicações na saúde e tem expectativas promissoras para o tratamento do câncer e doenças infecciosas, entre outras (CATTANEO et al, 2010).A descobertae desenvolvimentode novos fármacos, materiais implantáveis e dispositivos ou máquinas molecularesdimensionadosem escala nanométrica introduziram uma renovação expressiva nas estratégias de liberação controlada e direcionada de fármacos, do diagnóstico, substituição de tecidos, e / ou auxilios cirúrgicos. No final de 2009. o Instituto Nacional de Saúde norte-americano (NIH, BETHESDA, MA, USA; http://www.clinicaltrials.gov) mantinha quase 600 estudos clínicos usando nanoprodutos, sendo que $40 \%$ deles, nas fases I e II. Outros nanoprodutos se limitaram aos estudos in vitro, enquanto algumas nanodrogas já tem liberação para uso clinico (CATTANEO et al, 2010).

Os sistemas de carreamento e liberação de drogas estão entre os que possuem maior potencial de aplicação na nanomedicina. Eles protegem o fotossensibilizante do ambiente externo, evitam a sua agregação, melhoram a acumulação seletiva no tecido doente e liberação sustentável e assim, melhoram a eficácia terapêutica, reduzem efeitos colaterais e a toxicidade e aumentam a biodisponibilidade dos fármacos (SILVA et al, 2013).

Entre os principais sistemas nanoestruturados para carreamento de fármacos e vacinas, temos os lipossomas, ciclodextrinas, dendrímeros, nanopartículas poliméricas, nanopartículas inteligentes, nanopartículas magnéticas, loções coloides e emulsões (ROSSI-BERGMANN, 2008; ARAUJO; THOMAZINE; LOPEZ, 2010; ZHANG et al, 2011).

Os lipossomas têm como desvantagens a baixa eficiência de incorporação, instabilidade e custo alto (ZHANG et al, 2011). Ao contrário dos lipossomas, as partículas poliméricas não possuem um núcleo aquoso, mas sim uma matriz sólida constituída de polímeros. O fármaco é agregado, encapsulado ou adsorvido às partículas, e, dependendo do método de preparação, pode-se obter nanoesferas ou nanocápsulas. O fármaco é liberado gradualmente da partícula por erosão ou difusão (ROSSI-BERGMANN, 2008).

Devido a sua maior estabilidade e durabilidade, as nanopartículas podem ser estocadas em temperatura ambiente por tempo prolongado. Elas têm 
sido usadas em próteses ortopédicas, fios de sutura biodegradáveis, carreadores de DNA (terapia gênica) e veiculação de quimioterápicos para o tratamento de câncer cerebral e de próstata (ROSSI-BERGMANN, 2008).

As nanoemulsões são bem aceitas por aumentarem a permeabilidade da pele às substancias lipofílicas, hidrofílicas e anfifílicas, além de conferirem estabilidade à droga e terem ação prolongada (ARAUJO; THOMAZINE; LOPEZ, 2010; ZHANG et al, 2011). Por fim ressalta-se a boa tolerabilidade das nanocarreadores na pele (ZHANG et al, 2011; PASSOS, 2012).

A fase oleosa, o tipo de emulsão e o fármaco usado são considerados fatores que interferem na penetração cutânea dos medicamentos. Em emulsões água/óleo $(\mathrm{A} / \mathrm{O})$, o principal mecanismo que rege a penetração cutânea é a taxa de liberação do medicamento da fase interna. Por outro lado, em emulsões óleo/água (O/A) de óleo de soja, a penetração através de folículos pilosos e a atividade termodinâmica do agente são os fatores possivelmente predominantes. (ZHANG et al, 2011).

Com o objetivo de melhorar a estabilidade, aumentar a penetração e, portanto, a eficácia da TFD, assim como reduzir o tempo de oclusão do ALA, foi desenvolvida uma nanoemulsão lipídico-polimérica para veiculação do ALA (Nano$A L A)$, aplicando dessa forma a nanotecnologia em um sistema de entrega de drogas usadas em terapia fotodinâmica. Cabe ressaltar que já foram conduzidos estudos de terapia fotodinâmica com o Nano-ALA no qual foi veiculado ALA $20 \%$. Este sistema apresentou excelente eficácia, tolerabilidade para tratamento das ceratoses actínicas, carcinoma basocelular superficial e doença de Bowen, como verificado aos 3 e 12 meses de seguimento (PASSOS, 2012).

\subsection{Fontes de luz}

Uma fonte de luz com espectro de emissão que corresponde ao espectro de absorção do agente fotossensibilizante é condição necessária para se determinar a eficácia do procedimento. A absorção máxima da luz pelas porfirinas está próxima de $405 \mathrm{~nm}$. Essa faixa de absorção máxima é denominada de 
Soretband. Outros picos menores de absorção, chamados de Q-bands, se encontram em 510, 545, 580 e $630 \mathrm{~nm}$.

Embora a luz azul coincida com o pico de absorção das porfirinas, possibilitando ativação fotodinâmica, a sua penetração é suficiente somente para o tratamento de lesões superficiais. Por sua vez, a luz vermelha oferece maior penetração no tecido e está na faixa de comprimento de onda denominada de “janela óptica terapêutica”. Ela permite que a foto-oxidação dos tecidos tumorais seja efetiva tanto na lesão superficial (OSTLER et al, 2000), quanto nas lesões mais espessas, motivo pelo qual a maioria dos estudos clínicos é realizada com luz de comprimentos entre 625 e 633 nm (KALKA; MERK; MUKHTAR, 2000).

Embora a luz vermelha com comprimento de onda de $635 \mathrm{~nm}$ seja capaz de penetrar cerca de $6 \mathrm{~mm}$ na pele, enquanto as de comprimento de onda entre 400 e $500 \mathrm{~nm}$ penetram apenas 1 a $2 \mathrm{~mm}$, sua espessura terapeuticamente efetiva parece estar entre 1 e $3 \mathrm{~mm}$. Isso se deve à capacidade de produção da reação fotodinâmica, a qual dependerá da dose de luz e também da quantidade de fotossensibilizante no tecido alvo (MORTON, 2004).

A eficácia clínica da TFD depende da dosimetria, isto é, da dose total de energia, do tempo de exposição à luz e do modo de liberação da luz, ou seja, se simples ou fracionada. A fluência também pode afetar a resposta à TFD (HENDERSON, BUSCH, SNYDER, 2006). As energias utilizadas normalmente variam de 50 a $150 \mathrm{mw} / \mathrm{cm}^{2}$, enquanto o tempo de exposição à luz varia de modo inverso à energia. Além disso, nas energias mais altas pode ocorrer um efeito térmico aditivo em relação à fluência (TOREZAN, 2011) ou, em outras palavras, à dose total de luz utilizada durante a sessão de TFD. Os tumores malignos necessitam, em geral, de fluências maiores.

Entre as fontes de luz não coerentes disponíveis e descritas em estudos clínicos de TFD no tratamento do câncer tem-se as lâmpadas de diodo (LED) e, mais recentemente, a luz intensa pulsada (ZELICKSON, 2005). Os LED (luz emitida por diodo) são componentes eletrônicos semicondutores ligados entre si e que geram luz. Fornecem uma fonte de luz confiável e de alta potência em faixas estreitas de bandas de luz (entre 20-50 nm) e podem ser distribuídos em painéis para promover a iluminação de uma superfície ampla e homogênea. Este aspecto é 
muito importante, pois uma distribuição irregular da luz pode deixar de tratar partes de um tumor superficial mais extenso. São de fácil uso e de meia vida longa (BABILAS et al, 2010).

Este trabalho tem o escopo de aprofundar o estudos prévios e comprovar a eficácia e tolerabilidade do Nano-ALA para o tratamento do carcinoma basocelular nodular com espessura de até $2 \mathrm{~mm}$, assim como comparar esse resultado ao do M-ALA, já em uso clínico. 


\section{MATERIAL E MÉTODOS}

\subsection{Delineamento da pesquisa}

Trata-se de um ensaio clínico prospectivo, randomizado, não cego, comparando Nano-ALA e M-ALA na terapia fotodinâmica de lesões de carcinoma basocelular nodular confirmadas pelo exame histopatológico, com espessura de até dois milímetros.

\subsubsection{Amostras fotossensibilizantes}

Neste trabalho foram empregados como agentes fotossensibilizantes Nano-ALA em concentração $20 \%$ de ALA e acondicionado em seringas de $1 \mathrm{~mL}$ (desenvolvido e manipulado pelo Grupo de Fotobiologia e Fotomedicina da Faculdade de Filosofia Ciências e Letras de Ribeirão Preto (FFCLFR-USP) e gentilmente cedido para realização desta pesquisa) ou creme contendo Metilaminolevulinato (M-ALA) 16\% (Metvix®; Galderma, França).

Como descrito por Passos (2012), para "a produção do Nano-ALA, o ALA foi encapsulado em uma nanoemulsão polimérica produzida a partir de ácido poliláctico-poliglicólico e de lípidesfosfatidilcolina (50:50), com tamanho médio variando de 100 a $300 \mathrm{~nm}$. A nanoemulsão polimérica de óleo-em-água foi preparada na presença de ALA pelo processo de emulsificação espontânea, conforme descrito na literatura (PRIMO et al, 2011). Em resumo, a fase orgânica (acetona ou mistura de solventes orgânicos) contendo triglicérides de cadeias médias, fosfolípides de soja naturais e ALA (Dye Pharmaceutical, Brasil), este último a uma concentração final de $20 \%$, foi preparada a $55^{\circ} \mathrm{C}$. Subsequentemente, esta solução orgânica foi adicionada à fase aquosa contendo o surfactante aniônico, poloxâmero 188 (Sigma-Aldrichco., St. Louis, MO, EUA), sob agitação magnética. O solvente orgânico foi removido por evaporação sob pressão reduzida a $60^{\circ} \mathrm{C}$ ". A amostra foi previamente caracterizada por microscopia eletrônica de transmissão e zetasizer (PASSOS, 2012). 


\subsubsection{Participantes e local da pesquisa}

Foram incluídos no estudo pacientes que frequentam os ambulatórios de dermatologia de tumores do Hospital Regional da Asa Norte em Brasília (HRAN), com diagnóstico histopatológico de carcinoma basocelular do tipo nodular de baixo risco e com espessura de até $2 \mathrm{~mm}$.

O diagnóstico foi confirmado pelo exame histopatológico após uma biopsia com punch de tamanho de 2,5 ou $3 \mathrm{~mm}$ no centro da lesão ou local que corresponde clinicamente à maior espessura do tumor. $\mathrm{O}$ material da biopsia foi encaminhado no mesmo dia em frasco de formol a $10 \%$, devidamente identificado, para o laboratório de análise histopatológica do HRAN e seguiu a rotina de serviços desse setor. Foi feita revisão das lâminas com outro serviço de laboratório particular para conferência dos laudos e da medida de espessura do tumor.

Foram incluídos no estudo 24 pacientes consecutivos, com um total de 30 lesões de $\mathrm{CBC}$ com espessura de até $2 \mathrm{~mm}$, que concordaram livremente participar da pesquisa e assinaram o termo de consentimento livre e esclarecido (apêndice I). A idade dos pacientes, aptos a tomarem decisões de modo pleno e livre, foi entre 38 e 84 anos.

Eram critérios de exclusão a história de doenças fotossensíveis (doenças que podem piorar com exposição à luz), como lúpus eritematoso e porfiria, assim como histórico de fotossensibilidade ou reações fotoalérgicas. Também foram excluídas gestantes e lactantes.

Os pacientes foram divididos em dois grupos de modo aleatório conforme a disponibilidade do material e as conveniências do serviço, tendo um grupo recebido Nano-ALA-TFD e outro M-ALA-TFD, conforme o protocolo citado adiante. 


\subsection{Procedimentos de coleta de dados}

\subsubsection{Preparo das lesões, coleta da amostra e TFD}

As lesões previamente selecionadas por estudos histológicos foram submetidas à antissepsia com clorexidina e posteriormente limpas com solução fisiológica $0,9 \%$. Foi então realizada curetagem superficial sem causar sangramento e, por fim, aplicado um dos dois fármacos fotossensibilizantes conforme técnicas utilizadas em estudos anteriores.

Nano-ALA ou M-ALA foi aplicado nas lesões, respeitando-se $5 \mathrm{~mm}$ de margem. Em seguida, as áreas foram ocluídas durante 3 horas com papel filme de PVC recoberto com papel alumínio fixado com esparadrapo microporoso. Após esse período, a oclusão foi retirada e as lesões lavadas com soro fisiológico e expostas à irradiação com luz visível no comprimento de onda na faixa da luz vermelha, de acordo com a substância fotossensibilizante usada, conforme segue (Tabela 2): (1) no grupo de pacientes em que foi usado Nano-ALA foi aplicada a cabeça PDT (MULTI WAVES® INDÚSTRIA, SÃO PAULO, BRASIL), tempo de exposição de 7 minutos e energia de $90 \mathrm{~mW}$ e a fluência de $37,8 \mathrm{~J} / \mathrm{s}$; (2) no grupo em que foi usado M-ALA como agente fotossensibilizante, fez-se o uso de LED de luz vermelha com comprimento de onda de $635 \mathrm{~nm}$ na dose de $37 \mathrm{~J} / \mathrm{cm} 2$ (AKTILITE $®$, PHOTOCURE, NORWAY).

Tabela 2 - Protocolos de TFD utilizados no estudo.

\begin{tabular}{|c|c|c|c|}
\hline Grupo & Agente fotossensibilizante & Fonte de luz & Energia/dose \\
\hline Grupo I & $\begin{array}{c}\text { Nano-ALA } \\
\text { (FFCLFR-USP) }\end{array}$ & $\begin{array}{c}\text { Luz vermelha - } \\
\text { 630nm } \\
\text { PDT-MultiWaves® }\end{array}$ & $\begin{array}{c}90 \mathrm{Mw} \\
\text { Fluência } 37,8 \mathrm{~J} / \mathrm{s}\end{array}$ \\
\hline Grupo II & $\begin{array}{c}\text { M-ALA } \\
\text { (Metvix® - Galderma) }\end{array}$ & $\begin{array}{l}\text { Luz vermelha - } \\
635 \mathrm{~nm} \\
\text { AKTILITE® }\end{array}$ & $37 \mathrm{~J} / \mathrm{cm}^{2}$ \\
\hline
\end{tabular}


Após o tratamento, os pacientes foram orientados a lavar a lesão com água e sabão e utilizar um creme cicatrizante (Fibrase $®$ ). Antibiótico sistêmico foi feito em caso de infecção secundária. $O$ mesmo procedimento foi repetido com intervalo de uma semana.

\subsubsection{Avaliação da eficácia e seguimento}

Os pacientes foram acompanhados em retornos para seguimento clínico 7, 14, 21 e 90 dias após a primeira aplicação.

A avaliação da eficácia foi feita clinicamente e histopatologicamente, três meses após a terapia fotodinâmica (90 dias após a primeira aplicação). A avaliação clínica consistiu em exame clínico pela pesquisadora que, com a ectoscopia, diagnosticava cura clínica ou persistência do tumor. Nessa mesma data, era feita biopsia excisional da área tratada para estudo histopatológico.

O estudo histopatológico por biópsia excisional após a TFD representa o padrão ouro de avaliação da eficácia do tratamento e objetivava também a cura do CBC. O resultado da biópsia excisional foi utilizado para investigar a acurácia do diagnóstico clínico pós-tratamento e eventuais fatores associados à falha terapêutica, como por exemplo a espessura do tumor, localização em área de risco e idade do paciente.

Após o término da pesquisa, os pacientes desse projeto mantiveramse acompanhados a cada 3 ou 6 meses, de acordo com o grau de comprometimento actínico da sua pele em geral e de acordo com os protocolos estabelecidos para o tipo de doença. Este procedimento vem sendo realizado no serviço de Dermatologia do HRAN. 


\subsubsection{Avaliação de tolerabilidade}

\subsubsection{Avaliação da dor}

A dor e ardência foram avaliadas durante o tratamento por uma escala numérica verbal, sendo todos os pacientes solicitados para avaliar a intensidade da dor e dar nota de zero a 10, sendo zero a ausência de dor e 10, o valor máximo verificado logo após cada aplicação.

\subsubsection{Avaliação de outros efeitos adversos}

A presença ou ausência dos efeitos adversos imediatos, como edema e eritema, foram observadas logo após cada aplicação e avaliados em escala semiquantitativa variando de um a quatro em ordem crescente de intensidade. Formação de crostas, infecção e ulceração foram investigadas clinicamente uma semana após o tratamento.

\subsection{Procedimentos éticos}

Este projeto foi submetido e aprovado pelo Comitê de Ética para pesquisa com seres humanos (liberada na Plataforma Brasil em setembro de 2013) e foi realizado de acordo com os critérios estabelecidos pela Resolução 196/96 do Conselho Nacional de Saúde. Os pacientes somente foram incluídos na pesquisa após assinarem o Termo de Consentimento Livre e Esclarecido (TCLE), conforme modelo no Apêndice I.

\subsection{Análise estatística}

Para a análise estatística, foram executadas as estatísticas descritivas, como cálculo das frequências relativas e o resumo estatístico das variáveis contínuas (medidas de tendência central e de dispersão). Para comparação de proporções, utilizou-se o teste exato de Fisher. Para comparação de variáveis 
contínuas e ordinais, foi utilizado o teste U de Mann-Whitney e o teste de Wilcoxon, para amostras não pareadas e pareadas respectivamente. A correlação entre variáveis contínuas sem distribuição normal foi testada pelo teste de Spearman. Os dados foram analisados no programa SPSS® versão 20.0. O nível de significância adotado foi de $5 \%$. 


\subsection{Caracterização clínica do carcinoma basocelular nodular}

Os participantes do estudo apresentavam lesões clínicas suspeitas de $\mathrm{CBC}$ e tiveram confirmação diagnóstica de CBC nodular após biopsia por punch.A figura 4 ilustra a apresentação clínica de tumores de 4 sujeitos da pesquisa.

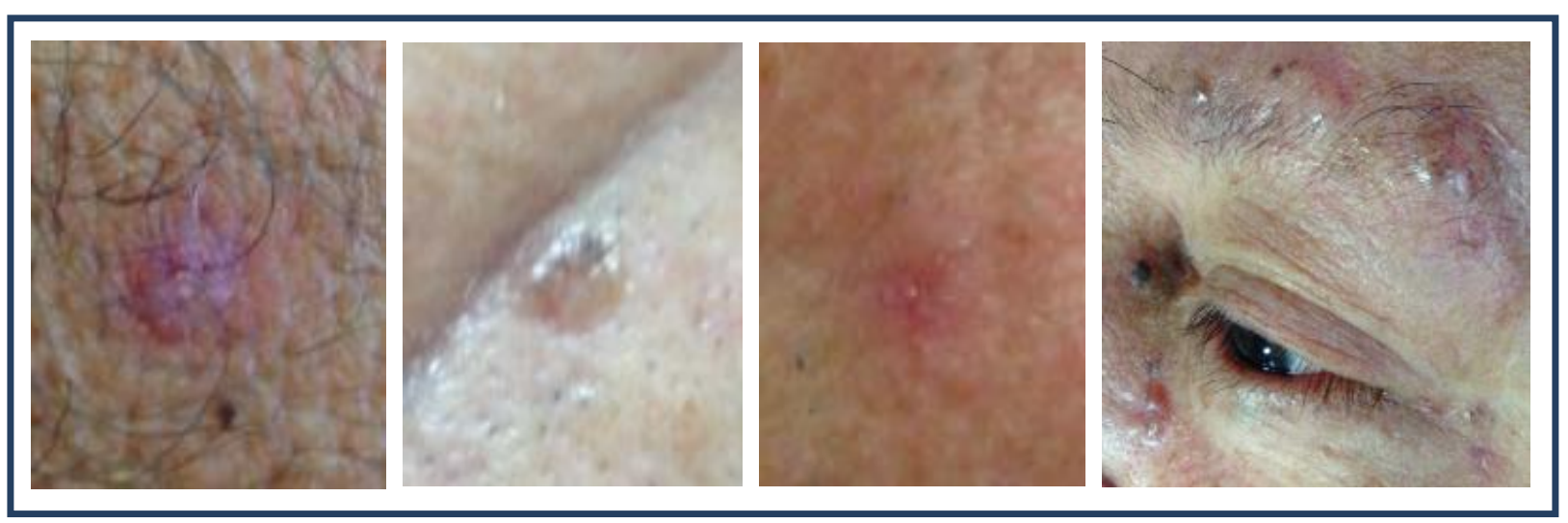

Figura 4 - Fotos llustrativas da apresentação clinica de CBC nodular em quatro participantes da pesquisa. Destaca-se a multiplicidade das lesões observadas na última foto (Fotografias de autoria da pesquisadora).

\subsection{Caracterização do processo de TFD}

A figura 5 ilustra a terapia fotodinâmica de dois participantes da pesquisa tratados com M-ALA, com imagens do tumor pré-TFD e pós-TFD e imagens de fluorescência da primeira e segunda sessão, destacando-se a maior intensidade dessa na segunda aplicação de TFD. 


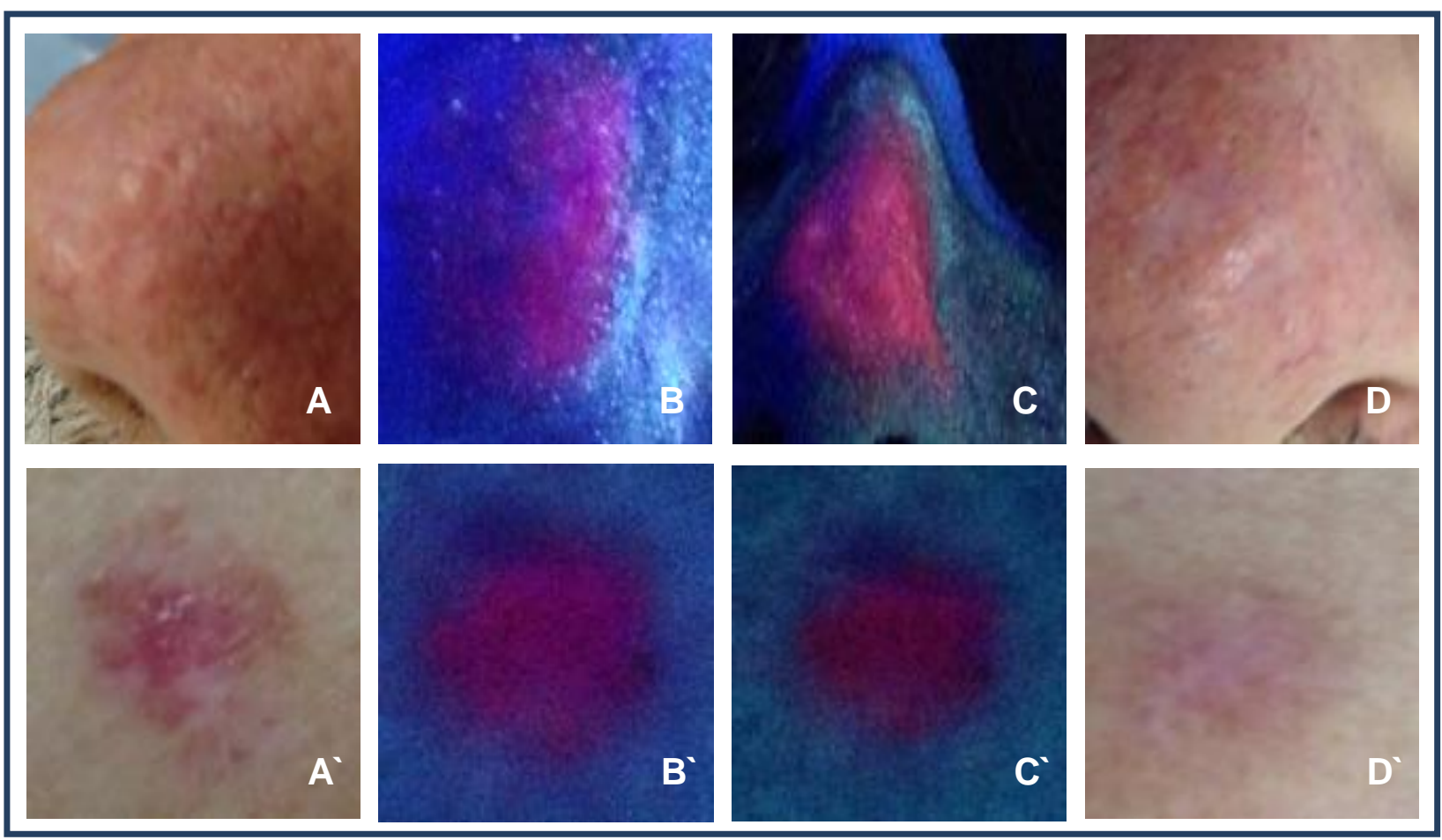

Figura 5 - Fotos ilustrativas do processo de M-ALA-TFD em dois participantes da pesquisa. Da esquerda para direta:(A) lesão pré- tratamento, (B) fluorescência na primeira sessão,(C) fluorescência na segunda sessão e (D) lesão 3 meses após o tratamento. Destaca-se a maior intensidade da fluorescência na segunda sessão em relação à primeira. (Fotografias de autoria da pesquisadora).

\subsection{Caracterização da população amostral investigada}

Foram tratadas 30 lesões de CBC nodular em 24 pacientes, 12 dos quais homens (50\%). A idade média dos participantes da pesquisa era de 62 anos e 75\% tinham tipo de pele II ou III de acordo com a classificação de Fitzpatrick e 75\% possuíam olhos de cor escura.

Após divisão aleatória das 30 lesões em dois grupos, 14 lesões de 14 indivíduos foram incluídas no grupo Nano-ALA e 16 lesões de 11 indivíduos no grupo M-ALA (um mesmo paciente teve uma lesão tratada com Nano-ALA e outra com M-ALA). A média de idade foi semelhante nos dois grupos (62 anos no grupo M-ALA e 64 no M-ALA). As características dos indivíduos quanto a sexo, tipo de pele e cor dos olhos nos grupos de tratamento é apresentada na tabela 3, não havendo diferença estatisticamente significante. 
Tabela 3 - Características dos sujeitos da pesquisa quanto ao sexo, tipo de pele, e cor dos olhos nos grupos de tratamento.

\begin{tabular}{|c|c|c|c|c|c|c|c|c|}
\hline & & \multicolumn{6}{|c|}{ Tratamento } & \multirow{3}{*}{$P^{*}$} \\
\hline & & \multicolumn{2}{|c|}{ Nano-ALA } & \multicolumn{2}{|c|}{ M-ALA } & \multicolumn{2}{|c|}{ Total } & \\
\hline & & $\mathrm{N}$ & $\%$ & $\mathrm{~N}$ & $\%$ & $\mathrm{~N}$ & $\%$ & \\
\hline \multirow[t]{3}{*}{ Sexo } & Masculino & 7 & 50,0 & 9 & 56,3 & 16 & 53,3 & \\
\hline & Feminino & 7 & 50,0 & 7 & 43,7 & 14 & 46,7 & 1,00 \\
\hline & Total & 14 & 100 & 16 & 100 & 30 & 100 & \\
\hline Tipo de pele & 1 & 0 & 0,0 & 2 & 12,5 & 2 & 6,7 & \\
\hline \multirow[t]{4}{*}{$\left(\right.$ Fitzpatrick $\left.^{1}\right)$} & 2 & 7 & 50,0 & 2 & 12,5 & 9 & 30,0 & \\
\hline & 3 & 4 & 28,6 & 9 & 56,3 & 13 & 43,3 & 0,07 \\
\hline & 4 & 3 & 21,4 & 3 & 18,7 & 6 & 20,0 & \\
\hline & Total & 14 & 100 & 16 & 100 & 30 & 100 & \\
\hline \multirow{3}{*}{$\begin{array}{l}\text { Cor dos } \\
\text { Olhos }\end{array}$} & Escuros & 11 & 78,6 & 12 & 75,0 & 23 & 76,7 & \\
\hline & Claros & 3 & 21,4 & 4 & 25,0 & 7 & 23,3 & 1,00 \\
\hline & Total & 14 & 100 & 16 & 100 & 30 & 100 & \\
\hline
\end{tabular}

*Teste exato de Fisher

\subsection{Caracterização das lesões investigadas}

Quanto à localização, do total de 30 lesões de CBCn, 26 (86,7\%) localizavam-se na face, e 14 (46,7\%) em área consideradas de alto risco (46,70\%). Não foi observada diferença significativa do ponto de vista estatístico quanto à localização das lesões nos dois grupos (tabela 4). Entretanto, observa-se uma tendência numérica de maior número de lesões em áreas de alto risco no grupo

\footnotetext{
${ }^{1}$ Classificação de fototipos de Fitzpatrick (SUZUKI et al, 2011):

I-Branca - Sempre queima - Nunca bronzeia - Muito sensível ao Sol

II - Branca - Sempre queima - Bronzeia muito pouco - Sensível ao Sol

III - Morena clara - Queima (moderadamente)- Bronzeia (moderadamente) - Sensibilidade normal ao Sol

IV - Morena moderada - Queima (pouco) - Sempre bronzeia - Sensibilidade normal ao Sol

V - Morena escura - Queima (raramente) - Sempre bronzeia - Pouco sensível ao Sol

VI - Negra - Nunca queima - Totalmente pigmentada - Insensível ao Sol.
} 
tratado com Nano-ALA, com $64,3 \%$ das lesões em áreas de alto risco versus $31,2 \%$ no grupo do M-ALA, embora sem atingir significância estatística $(P=0,14)$.

Tabela 4 - Distribuição das lesões quanto à localização em tronco ou face e em área de risco nos dois grupos de tratamento, antes da intervenção.

\begin{tabular}{|c|c|c|c|c|c|c|c|c|}
\hline & & \multicolumn{6}{|c|}{ Tratamento } & \multirow{3}{*}{$P^{*}$} \\
\hline & & \multicolumn{2}{|c|}{ Nano-ALA } & \multicolumn{2}{|c|}{ M-ALA } & \multicolumn{2}{|c|}{ Total } & \\
\hline & & $\mathrm{N}$ & $\%$ & $\mathrm{~N}$ & $\%$ & $\mathrm{~N}$ & $\%$ & \\
\hline \multirow{3}{*}{ Localização } & Face & 11 & 78,6 & 15 & 93,7 & 26 & 86,7 & \multirow{3}{*}{0,32} \\
\hline & Tronco & 3 & 21,4 & 1 & 6,3 & 4 & 13,3 & \\
\hline & Total & 14 & 100 & 16 & 100 & 30 & 100 & \\
\hline \multirow{3}{*}{ Área de risco } & Alto & 9 & 64,3 & 5 & 31,2 & 14 & 46,7 & \multirow{3}{*}{0,14} \\
\hline & Baixo & 5 & 35,7 & 11 & 68,8 & 16 & 53,3 & \\
\hline & Total & 14 & 100 & 16 & 100 & 30 & 100 & \\
\hline
\end{tabular}

*Teste exato de Fisher.

Em relação ao tamanho da lesão e espessura histológica do tumor no total de 30 lesões, a média foi de $8,97 \mathrm{~mm}$ e $1,18 \mathrm{~mm}$ respectivamente. Não houve diferença significativa acerca desses parâmetros nos dois grupos (tabela 5).

Tabela 5 - Tamanho da lesão e espessura histológica do tumor antes da terapia fotodinâmica nos dois grupos de tratamento.

\begin{tabular}{|c|c|c|c|c|c|c|c|}
\hline & \multicolumn{6}{|c|}{ Tratamento } & \multirow{3}{*}{$P^{*}$} \\
\hline & \multicolumn{2}{|c|}{ Nano-ALA } & \multicolumn{2}{|r|}{ M-ALA } & \multicolumn{2}{|r|}{ Total } & \\
\hline & Média & Erro padrão & Média & Erro padrão & Média & Erro padrão & \\
\hline Tamanho da lesão (mm) & 9,64 & 1,01 & 8,38 & 0,46 & 8,97 & 0,53 & 0,59 \\
\hline Espessura do tumor (mm) & 1,21 & 0,14 & 1,16 & 0,14 & 1,18 & 0,10 & 0,62 \\
\hline
\end{tabular}

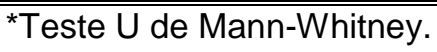




\subsection{Relações entre espessura pré-tratamento do tumor e tamanho e local da lesão}

Os dados do tumor antes do tratamento com a terapia fotodinâmica foram também usados para avaliar se havia correlação entre o tamanho da lesão e a sua espessura. No gráfico 1 é mostrada a distribuição dos dados coletados em análise bivariada destas duas características. Foi possível constatar ausência de correlação, com coeficiente de correlação $r=0,03$ e $P=0,6$ (teste de Spearman).

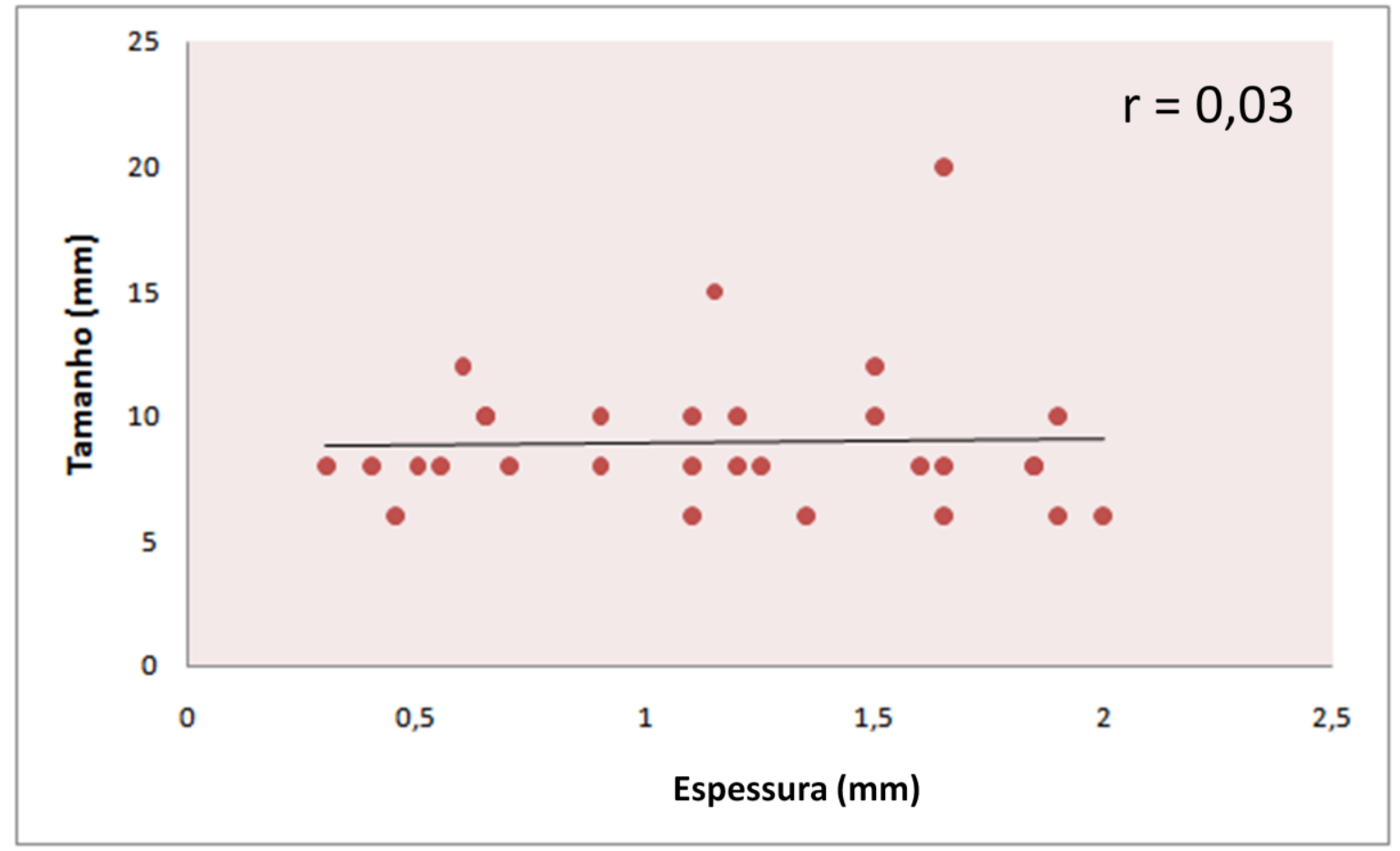

Gráfico 1 - Distribuição das lesões conforme tamanho e espessura antes da terapia fotodinâmica.

$\mathrm{Na}$ Tabela 6, é apresentada a espessura do tumor nas áreas de alto e baixo risco. A espessura média do tumor na área de alto risco era de 1,23 $\mathrm{mm}$ e na área de baixo risco era de $1,14 \mathrm{~mm}$, sem diferença significativa do ponto de vista estatístico. 
Tabela 6 - Espessura do tumor em áreas de alto risco ou de baixo risco antes da intervenção com terapia fotodinâmica.

\begin{tabular}{|c|c|c|c|c|c|c|c|}
\hline & \multicolumn{6}{|c|}{ Áreas de risco } & \multirow{3}{*}{$P^{*}$} \\
\hline & \multicolumn{2}{|c|}{ Alto } & \multicolumn{2}{|c|}{ Baixo } & \multicolumn{2}{|c|}{ Total } & \\
\hline & Média & $\begin{array}{c}\text { Erro } \\
\text { padrão }\end{array}$ & Média & $\begin{array}{c}\text { Erro } \\
\text { padrão }\end{array}$ & Média & $\begin{array}{c}\text { Erro } \\
\text { padrão }\end{array}$ & \\
\hline Espessura do tumor (mm) & 1,23 & 0,12 & 1,14 & 0,15 & 1,18 & 0,10 & 0,62 \\
\hline
\end{tabular}

${ }^{*}$ Teste U de Mann-Whitney.

A espessura do tumor em áreas de alto e baixo risco foi estratificada por grupos de tratamento, não sendo observada também diferença significativa (tabela 7).

Tabela 7 - Espessura do tumor em áreas de alto risco ou de baixo risco nos dois grupos de tratamento antes da intervenção com terapia fotodinâmica.

\begin{tabular}{|c|c|c|c|c|c|c|c|c|c|c|}
\hline & \multicolumn{9}{|c|}{ Grupo de tratamento } & \multirow{5}{*}{$\mathrm{P}^{*}$} \\
\hline & \multirow{2}{*}{\multicolumn{4}{|c|}{$\begin{array}{c}\text { Nano-ALA } \\
\text { Risco }\end{array}$}} & \multirow{4}{*}{$P^{*}$} & \multirow{2}{*}{\multicolumn{4}{|c|}{$\frac{\text { M-ALA }}{\text { Risco }}$}} & \\
\hline & & & & & & & & & & \\
\hline & \multicolumn{2}{|c|}{ Alto } & \multicolumn{2}{|c|}{ Baixo } & & \multicolumn{2}{|c|}{ Alto } & \multicolumn{2}{|c|}{ Baixo } & \\
\hline & Média & $\begin{array}{l}\text { Erro } \\
\text { padrão }\end{array}$ & Média & $\begin{array}{l}\text { Erro } \\
\text { padrão }\end{array}$ & & Média & $\begin{array}{l}\text { Erro } \\
\text { padrão }\end{array}$ & Média & $\begin{array}{l}\text { Erro } \\
\text { padrão }\end{array}$ & \\
\hline $\begin{array}{l}\text { Espessura do tumor } \\
\qquad(\mathrm{mm})\end{array}$ & 1,15 & 0,17 & 1,33 & 0,27 & 0,89 & 1,38 & 0,16 & 1,05 & 0,19 & 0,46 \\
\hline
\end{tabular}

${ }^{*}$ Teste U de Mann-Whitney.

\subsection{Avaliação de eficácia}

Após a intervenção com terapia fotodinâmica, a avaliação clínica indicava a ausência do tumor em 66,7\% das lesões. Entretanto, a cura histológica ocorreu em apenas metade do total de lesões tratadas (tabela 8).

No grupo tratado com Nano-ALA, a taxa de cura histológica foi de $35,7 \%$, enquanto no grupo tratado com M-ALA a taxa de cura foi de $62,5 \%$. Apesar 
da aparente diferença numérica, não houve significância estatística, com $P=0,27$ (tabela 8).

Entre as 15 lesões não curadas, 11 (73\%) mantinham o padrão histopatológico de CBC nodular (tabela 8). Nas outras quatro, houve mudança do diagnóstico histopatológico do $\mathrm{CBC}$, sendo uma para $\mathrm{CBC}$ multifocal, uma para o tipo adenóide e duas para o tipo pigmentado (tabela 8). Esses quatro tumores com tipos e subtipos histológicos distintos ocorreram apenas no grupo tratado com Nano$A L A$, ou seja, nenhum no grupo M-ALA $(P=0,03)$.

Tabela 8 - Cura clínica e histológica após a terapia fotodinâmica.

\begin{tabular}{|c|c|c|c|c|c|c|c|c|}
\hline & & \multicolumn{6}{|c|}{ Tratamento } & \multirow{3}{*}{$P^{*}$} \\
\hline & & \multicolumn{2}{|c|}{ Nano-ALA } & \multicolumn{2}{|c|}{ M-ALA } & \multicolumn{2}{|c|}{ Total } & \\
\hline & & $\mathrm{N}$ & $\%$ & $\mathrm{~N}$ & $\%$ & $\mathrm{~N}$ & $\%$ & \\
\hline \multirow{3}{*}{ Cura clínica } & Sim & 7 & 50,0 & 13 & 81,2 & 20 & 66,7 & \multirow{3}{*}{0,12} \\
\hline & Não & 7 & 50,0 & 3 & 18,8 & 10 & 33,3 & \\
\hline & Total & 14 & 100 & 16 & 100 & 30 & 100 & \\
\hline \multirow{3}{*}{$\begin{array}{c}\text { Cura } \\
\text { histológica }\end{array}$} & Sim & 5 & 35,7 & 10 & 62,5 & 15 & 50,0 & \multirow{3}{*}{0,27} \\
\hline & Não & 9 & 64,3 & 6 & 37,5 & 15 & 50,0 & \\
\hline & Total & 14 & 100 & 16 & 100 & 30 & 100 & \\
\hline \multirow{6}{*}{$\begin{array}{l}\text { Resultado do } \\
\text { exame pós- } \\
\text { tratamento }\end{array}$} & Negativo & 5 & 35,7 & 10 & 62,5 & 15 & 50,0 & \multirow{6}{*}{0,01} \\
\hline & Nodular & 5 & 35,7 & 6 & 37,5 & 11 & 36,7 & \\
\hline & Adenóide** & 1 & 7,1 & 0 & 0,0 & 1 & 3,3 & \\
\hline & Multifocal $^{\star *}$ & 1 & 7,1 & 0 & 0,0 & 1 & 3,3 & \\
\hline & Pigmentado** & 2 & 14,3 & 0 & 0,0 & 2 & 6,7 & \\
\hline & Total & 14 & 100,0 & 16 & 100,0 & 30 & 100,0 & \\
\hline
\end{tabular}

\footnotetext{
${ }^{*}$ Teste exato de Fisher.

${ }^{* *}$ Observação: Total de 4 casos de tipos e subtipos distintos de CBC nodular encontrados na biopsia pós-tratamento. Os quatro ocorreram no grupo tratado com Nano-ALA ( $P=0,03)$.
} 
A terapia fotodinâmica levou à redução da espessura média do tumor (Tabela 7) de 1,18 mm para 0,72 $\mathrm{mm}(\mathrm{P}<0,001)$. Quando os dois grupos foram analisados separadamente, constatou-se a redução da espessura do tumor foi significativa apenas no grupo do M-ALA, com $P<0,001$ (tabela 9).

Tabela 9 - Espessura do tumor nos dois grupos de tratamento antes e após a terapia fotodinâmica.

\begin{tabular}{lccccccc}
\hline \hline & \multicolumn{2}{c}{ Nano-ALA } & \multicolumn{2}{c}{ M-ALA } & \multicolumn{2}{c}{ Total } \\
& Média & EP & Média & EP & Média & EP \\
\hline Espessura pré-tratamento do tumor $(\mathrm{mm})$ & 1,21 & 0,14 & 1,16 & 0,14 & 1,18 & 0,10 \\
Espessura pós-tratamento do tumor $(\mathrm{mm})$ & 1,02 & 0,29 & 0,45 & 0,15 & 0,72 & 0,16 \\
\hline $\mathrm{P}$ & \multicolumn{2}{c}{0,28} & & 0,0002 & & 0,0003 \\
\hline \hline
\end{tabular}

*Teste de Wilcoxon.

\subsection{Relação entre o critério clínico e a análise histopatológica no desfecho do tratamento}

Para investigar a acurácia da avaliação clínica pós-TFD para o diagnóstico de cura ou persistência do tumor, foi comparado o diagnóstico clínico com o resultado da biopsia excisional (tabela 10). Entre os 20 casos diagnosticados clinicamente como curados, seis persistiam com tumor na biópsia (30\% de falsos negativos). Entre as 10 lesões nas quais suspeitou-se clinicamente da presença de tumor, em 9 houve confirmação histológica da neoplasia, havendo portanto 10\% de falsos positivos. Constatou-se então que a sensibilidade da avaliação clínica foi de $65,3 \%$ e a especificidade de $93,3 \%$. 
Tabela 10 - Cura clínica versus cura histológica nos grupos de tratamento.

\begin{tabular}{|c|c|c|c|c|c|c|c|c|c|c|c|c|c|}
\hline & & \multicolumn{12}{|c|}{ Grupo de tratamento } \\
\hline & & \multicolumn{4}{|c|}{ Nano-ALA } & \multicolumn{4}{|c|}{ M-ALA } & \multicolumn{4}{|c|}{ Total } \\
\hline & & \multicolumn{4}{|c|}{ Cura clínica } & \multicolumn{4}{|c|}{ Cura clínica } & \multicolumn{4}{|c|}{ Cura clínica } \\
\hline & & \multicolumn{2}{|c|}{ Sim } & \multicolumn{2}{|c|}{ Não } & \multicolumn{2}{|c|}{ Sim } & \multicolumn{2}{|c|}{ Não } & \multicolumn{2}{|c|}{ Sim } & \multicolumn{2}{|c|}{ Não } \\
\hline & & $\mathrm{N}$ & $\%$ & $\mathrm{~N}$ & $\%$ & $\mathrm{~N}$ & $\%$ & $\mathrm{~N}$ & $\%$ & $\mathrm{~N}$ & $\%$ & $\mathrm{~N}$ & $\%$ \\
\hline \multirow{3}{*}{$\begin{array}{c}\text { Cura } \\
\text { Histológica }\end{array}$} & $\operatorname{Sim}$ & 4 & 57,1 & 1 & 14,3 & 10 & 76,9 & 0 & 0 & 14 & 70,0 & 1 & 10,0 \\
\hline & Não & 3 & 42,9 & 6 & 85,7 & 3 & 23,1 & 3 & 100 & 6 & 30,0 & 9 & 90,0 \\
\hline & Total & 7 & 100 & 7 & 100 & 13 & 100 & 3 & 100 & 20 & 100 & 10 & 100 \\
\hline $\mathrm{P}^{*}$ & & \multicolumn{4}{|c|}{0,27} & \multicolumn{4}{|c|}{0,04} & \multicolumn{4}{|c|}{0,005} \\
\hline
\end{tabular}

*Teste exato de Fisher.

\subsection{Relação de fatores prognósticos e resposta ao tratamento}

Foram também analisados os fatores que eventualmente influenciaram a resposta ao tratamento. Para tanto, foi feita análise da associação entre o desfecho histopatológico no total de leões com algumas variáveis pré-tratamento como a faixa etária, a localização do tumor, o tamanho da lesão e a espessura histológica do tumor (tabela 11). Entre essas variáveis, houve associação significativa apenas entre localização da lesão em área de alto ou baixo risco com o desfecho histológico, sendo o número de casos curados maior em áreas de baixo risco $(P=0,0007)$. A taxa global de cura histológica nas lesões em áreas de alto risco foi de $14,3 \%$ versus $81,3 \%$ nas áreas de baixo risco. 
Tabela 11 - Cura histológica estratificada por área de risco, tamanho e espessura das lesões antes da terapia, e pela faixa etária do paciente.

\begin{tabular}{|c|c|c|c|c|c|c|}
\hline & & \multicolumn{4}{|c|}{ Cura histológica } & \multirow[b]{3}{*}{$\mathrm{P}^{*}$} \\
\hline & & \multicolumn{2}{|c|}{$\operatorname{Sim}$} & \multicolumn{2}{|c|}{ Não } & \\
\hline & & $\mathrm{N}$ & $\%$ & $\mathrm{~N}$ & $\%$ & \\
\hline \multirow{3}{*}{ Área de risco } & Alto & 2 & 14,3 & 12 & 85,7 & \multirow{3}{*}{0,0007} \\
\hline & & & & & & \\
\hline & Baixo & 13 & 81,3 & 3 & 18,8 & \\
\hline \multirow{2}{*}{$\begin{array}{l}\text { Tamanho da } \\
\text { lesão }\end{array}$} & Menos de $10 \mathrm{~mm}$ & 8 & 42,1 & 11 & 57,9 & \multirow{2}{*}{0,45} \\
\hline & $10 \mathrm{~mm}$ ou mais & 7 & 63,6 & 4 & 36,4 & \\
\hline \multirow{3}{*}{ Espessura } & Até $1 \mathrm{~mm}$ & 7 & 63,6 & 4 & 36,4 & \multirow{3}{*}{0,45} \\
\hline & & & & & & \\
\hline & 1 a $2 \mathrm{~mm}$ & 8 & 42,1 & 11 & 57,9 & \\
\hline \multirow{3}{*}{ Faixa etária } & $<65$ anos & 10 & 62,5 & 6 & 37,5 & \multirow{3}{*}{0,27} \\
\hline & & & & & & \\
\hline & 65 anos ou mais & 5 & 35,7 & 9 & 64,3 & \\
\hline
\end{tabular}

${ }^{*}$ Teste exato de Fisher.

\subsection{Eventos adversos com a terapia fotodinâmica}

Dor foi relatada por todos os pacientes do estudo e em escala numérica verbal de 0 a 10 , a média global de escore foi igual a 4,4 na primeira sessão e 6,8 na segunda sessão. Não houve diferença significativa no escore de dor entre os grupos tratados com Nano-ALA ou com M-ALA, tanto na primeira quanto na segunda sessão. Também não houve diferença significativa em relação a eritema e edema nos dois grupos, avaliado por escore de 1 a 4 , tanto na primeira quanto na segunda sessão (Tabela 12). 
Tabela 12 - Eventos adversos (dor, edema e eritema) nos dois grupos de tratamento na primeira e na segunda sessão de TFD.

\begin{tabular}{|c|c|c|c|c|c|c|c|c|c|c|c|c|c|}
\hline & \multicolumn{12}{|c|}{ Tratamento } & \multirow[b]{3}{*}{$P^{*}$} \\
\hline & \multicolumn{6}{|c|}{ Nano-ALA } & \multicolumn{6}{|c|}{ M-ALA } & \\
\hline & Mín. ** & $\mathrm{P} 25$ & Mediana & P75 & Máx. & Média & Mín ${ }^{* *}$ & P25 & Mediana & P75 & Máx. & Média & \\
\hline $\begin{array}{l}\text { Dor } 1^{\mathrm{a}} \\
\text { sessão }^{\star \star \star}\end{array}$ & 1 & 3 & 5 & 6 & 7 & 4,5 & 2 & 2 & 4 & 6 & 8 & 4,3 & 0,667 \\
\hline $\begin{array}{l}{\text { Dor } 2^{\mathrm{a}}}_{\text {sessão }} \\
\text { sesa }^{2}\end{array}$ & 2 & 4 & 7 & 8 & 10 & 6,3 & 2 & 3 & 6 & 8 & 10 & 5,4 & 0,294 \\
\hline $\begin{array}{l}\text { Eritema } 1^{a} \\
\text { sessão }^{* \star *}\end{array}$ & 1 & 2 & 2 & 3 & 3 & 2,4 & 2 & 2 & 2 & 3 & 4 & 2,5 & 0,728 \\
\hline $\begin{array}{l}\text { Eritema }^{\mathrm{a}} \\
\text { sessão }^{\mathrm{a}}\end{array}$ & 1 & 2 & 3 & 4 & 4 & 2,9 & 1 & 2 & 3 & 3 & 3 & 2,5 & 0,294 \\
\hline $\begin{array}{l}\text { Edema } 1^{a} \\
\text { sessão }\end{array}$ & 1 & 2 & 2 & 3 & 4 & 2,3 & 2 & 2 & 2 & 3 & 4 & 2,5 & 0,423 \\
\hline $\begin{array}{l}\text { Edema } 2^{a} \\
\text { sessão }\end{array}$ & 1 & 2 & 3 & 4 & 4 & 2,8 & 2 & 2 & 3 & 3 & 4 & 2,6 & 0,637 \\
\hline
\end{tabular}

*Teste $U$ de Mann-Whitney.

**Mín. = valor mínimo; Máx. = valor máximo.

***Escore de dor: escala numérica verbal de 0 a 10; Eritema e edema: escala de 1 a 4.

Ao se comparar a intensidade da dor entre a primeira e a segunda sessão, foi observado aumento significativo na segunda sessão no grupo tratado com Nano-ALA ( $P=0,02$; Gráfico 2). Na comparação intragrupo de eritema e edema, entretanto, não houve diferença significativa entre os escores encontrados na primeira e na segunda sessão de TFD (Tabela 13). 


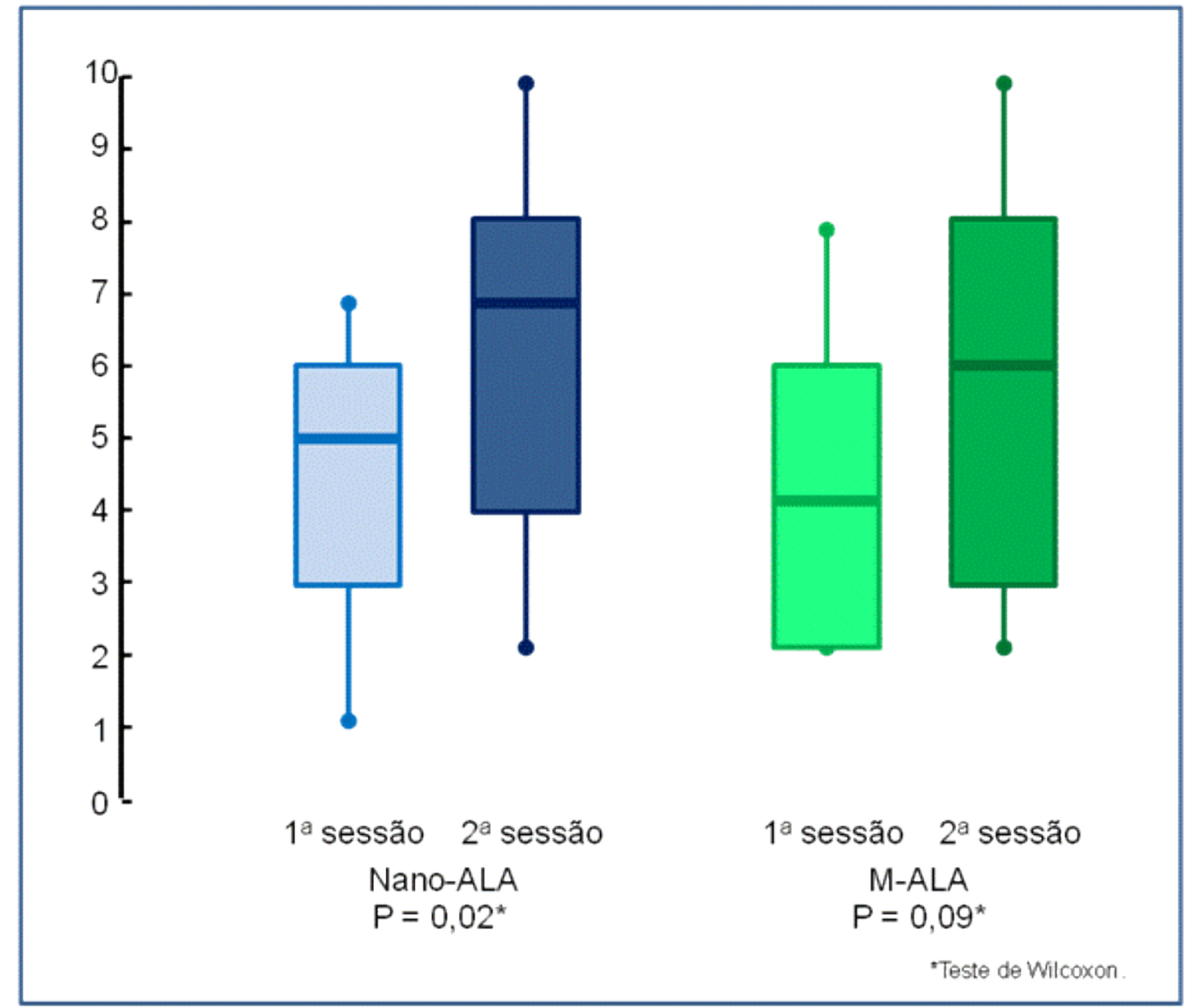

Gráfico 2 - Dor na primeira e na segunda sessão de TFD no grupo tratado com Nano-ALA e no grupo tratado com M-ALA. Valores mínimo e máximo (extremidades), percentis 25 e 75 (limites do retângulo) e mediana traço horizontal central). 
Tabela 13 - Comparação intragrupo do eritema e edema após a primeira e segunda sessões de TFD nos dois grupos de tratamento.

\begin{tabular}{|c|c|c|c|c|c|c|c|c|c|c|c|c|}
\hline & \multicolumn{12}{|c|}{ Tratamento } \\
\hline & \multicolumn{6}{|c|}{ Nano-ALA } & \multicolumn{6}{|c|}{ M-ALA } \\
\hline & Mín. ** & $\mathrm{P} 25$ & Mediana & P75 & Máx. & Média & Mín ** & P25 & Mediana & P75 & Máx." & Média \\
\hline $\begin{array}{l}\text { Eritema } 1^{a}{ }^{a} \\
\text { sessão }\end{array}$ & 1 & 2 & 2 & 3 & 3 & 2,4 & 2 & 2 & 2 & 3 & 4 & 2,5 \\
\hline $\begin{array}{l}\text { Eritema } 2^{\mathrm{a}} \\
\text { sessão }^{*+*}\end{array}$ & 1 & 2 & 3 & 4 & 4 & 2,9 & 1 & 2 & 3 & 3 & 3 & 2,5 \\
\hline$P^{*}$ & \multicolumn{6}{|c|}{0,088} & \multicolumn{6}{|c|}{0,999} \\
\hline $\begin{array}{l}\text { Edema } 1^{a} \\
\text { sessão" }\end{array}$ & 1 & 2 & 2 & 3 & 4 & 2,3 & 2 & 2 & 2 & 3 & 4 & 2,5 \\
\hline $\begin{array}{l}\text { Edema } 2^{\mathrm{a}} \\
\text { sessãot }\end{array}$ & 1 & 2 & 3 & 4 & 4 & 2,8 & 2 & 2 & 3 & 3 & 4 & 2,6 \\
\hline$P^{*}$ & \multicolumn{6}{|c|}{0,999} & \multicolumn{6}{|c|}{0,480} \\
\hline
\end{tabular}

*Teste U de Mann-Whitney.

**Mín. = valor mínimo; Máx. = valor máximo.

***Escore de dor: escala numérica verbal de 0 a 10; Eritema e edema: escala de 1 a 4. 


\section{DISCUSSÃO}

\subsection{Aspectos demográficos e das lesões}

O presente estudo é um ensaio clínico prospectivo, randomizado, não cego, cujo escopo é comparar a eficácia e tolerabilidade entre Nano-ALA e M-ALA no tratamento do carcinoma basocelular nodular com espessura de até $2 \mathrm{~mm}$ por terapia fotodinâmica. Foram tratadas trinta lesões de CBC nodular em 24 pacientes com idade média de 62 anos, variando entre 38 e 84 anos, com distribuição semelhante entre os gêneros ( $50 \%$ de homens). Os fototipos mais comuns foram os tipos II e III (75\% no total pela classificação de Fitzpatrick) e a maioria das lesões se localizou na face (86,7\%). O perfil demográfico e o das lesões estudadas são semelhantes aos descritos para o CBC nodular na literatura (CHINEM; MIOT, 2011).

As lesões de CBC nodular tratadas nesse estudo tinham em média 9 $\mathrm{mm}$ de diâmetro e espessura média de 1,18 mm, avaliada por biopsia por punch prétratamento. Não foi encontrada correlação entre diâmetro e espessura das lesões $(r=0,03)$, o que é corroborado pela literatura científica e é explicado pela característica de crescimento expansivo dessa variante histológica de CBC, tendendo a aumentar lentamente de tamanho para áreas com menor resistência, o que pode ocorrer proporcionalmente mais em diâmetro que em espessura (CHINEM; MIOT, 2011).

Do ponto de vista estatístico, não houve diferença entre as características demográficas e das lesões nos dois grupos de tratamento (Nano-ALA e M-ALA), indicando randomização satisfatória. As dimensões do tumor eram semelhantes nos dois grupos de tratamento, assim como a frequência de localização em face comparada à localização em tronco. Entretanto, observou-se uma maior frequência de lesões em áreas de alto risco no grupo Nano-ALA comparado ao grupo M-ALA (64,3\% versus $31,2 \%$, respectivamente), embora essa diferença não tenha atingido significância estatística $(P=0,14)$. 
A diferença encontrada na frequência de lesões em área de alto risco entre os dois grupos provavelmente decorre do acaso. Embora a randomização dos pacientes não tenha sido feita por lista gerada por computador, a alocação nos dois grupos de tratamento foi completamente aleatória, dependendo da disponibilidade do agente fotossensibilizante no serviço. Essa ocorria ao acaso e, durante o estudo, havia apenas um agente disponível por vez, evitando assim uma eventual "escolha" do pesquisador. Além do mais, a semelhança das demais características dos pacientes e das lesões nos dois grupos reforça que a randomização tenha sido satisfatória.

A pesquisa foi limitada ao tipo histológico nodular, por esta ser a variante mais comum de $\mathrm{CBC}$ e por localizar-se preferencialmente em face, onde a vantagem estética da TFD em relação à cirurgia é mais relevante. Além do mais, embora existam muitos estudos nos últimos anos avaliando a eficácia de ALA-TFD e M-ALA-TFD para o CBC nodular, ainda não existe publicação avaliando o uso do Nano-ALA, não há protocolo claro de orientação clínica definido e os resultados dos estudos são discrepantes, com variação de eficácia entre 10 até 76\% (FANTINI et al, 2011).

Entre os fatores que contribuem para a variabilidade dos resultados de eficácia destaca-se a falta de critérios para definição das lesões a serem tratadas, como tamanho, localização e espessura do tumor (GUPTA; REYDER, 2003; MOSTERD et al, 2008; FANTINI et al, 2011). No presente estudo, restringimos o diâmetro das lesões para até $20 \mathrm{~mm}$ e a espessura do tumor em até $2 \mathrm{~mm}$, já que os guidelines recomendam que a TFD para M-ALA seja limitada aos CBC nodulares finos. No entanto, exceto pelo trabalho de Fantini (2011) que sugere que a espessura seja de até $2 \mathrm{~mm}$, não há consenso acerca da definição exata dessa medida.

A espessura do tumor pré-tratamento foi determinada por biopsia por punch no centro da lesão ou em áreas onde o exame clínico sugerisse que a espessura do tumor fosse maior. Esse procedimento, embora não garanta que a amostra obtida represente a espessura real da lesão (MORTON et al, 2013; 
MOSTERD et al, 2008; COSGAREA et al, 2013), é o método utilizado em outros estudos de TFD. Apesar dessa limitação da biopsia por punch, esse é o método de escolha para avaliar a espessura do tumor sem a excisão completa da lesão, o que obviamente inviabilizaria estudos com TFD.

Existem inúmeras variáveis na TFD para tratamento do $\mathrm{CBC}$, tais como tipo de agente fotossenssibilizador, o emprego de diferentes métodos físicos e químicos para aumentar a penetração do agente, o tempo de oclusão, o tipo de iluminação e o número dos ciclos aplicados. No presente estudo, optamos por aplicar o protocolo padrão para M-ALA-TFD citado por Morton (2013), e utilizar os mesmos princípios para o Nano-ALA, ou seja, um ciclo de duas sessões com intervalo de uma semana, com aplicação de uma camada de $1 \mathrm{~mm}$ da medicação sobre a lesão e até $5 \mathrm{~mm}$ de margens após curetagem não sangrante e não dolorosa.

Apesar de alguns estudos mostrarem maior eficácia da TFD com a realização de shaving três semanas antes, a fim de reduzir a espessura do tumor (BABILAS et al, 2010; MORTON et al, 2013), no presente estudo optou-se por não realizar esse procedimento pois o estudo foi limitado ao tratamento de tumores finos, com no máximo $2 \mathrm{~mm}$ de espessura.

A iluminação foi feita após 3 horas de oclusão com ambos os produtos. Não obstante o tempo de oclusão recomendado para ALA-TFD variar de 4 a $18 \mathrm{~h}$ (MORTON et al, 2013), baseamos nosso estudo em trabalho anteriormente realizado com o Nano-ALA, o qual mostrou não haver diferença na espectrometria da fluorescência e nos resultados entre 3 e 4 horas de oclusão. Por se tratar de nanoemulsão, a velocidade de penetração do pró-fármaco deve ser aumentada, obtendo-se assim a mesma eficácia nesses dois tempos de oclusão (PASSOS, 2012),

Considerando que o CBC é um tipo de neoplasia maligna, do ponto de vista oncológico o objetivo do tratamento é sempre que possível a erradicação do tumor. Dessa forma, foi feita biopsia excisional de toda a lesão após o tratamento com TFD, com objetivo de aumentar as chances de cura. A excisão cirúrgica é um 
tratamento que reconhecidamente oferece maior índice de cura que a TFD no CBC nodular. Um estudo randomizado com 105 lesões de CBCn, comparando M-ALATFD e cirurgia, mostrou $96 \%$ de resposta completa sustentada em cinco anos de seguimento após a cirurgia e menor índice de recorrência nesse período que a TFD (RHODES et al, 2007).

Outra vantagem em realizar a biopsia excisional após a TFD no presente estudo é que esse procedimento é padrão ouro para o diagnóstico de cura ou não do tumor, eliminando possíveis vieses relacionados aos critérios clínicos usados para avaliar a eficácia da TFD. A maioria dos estudos que avaliam a eficácia da TFD analisa a resposta três meses após o tratamento e adota o critério clinico de resposta, especificado como clareamento parcial ou total das lesões. O critério histopatológico, quando aplicado, é feito mais comumente por meio de biopsia incisional que, vale dizer, pode ser feita em local que pode não retratar a realidade (ROOZEBOOM et al, 2012; MOSTERD et al, 2008). Em conclusão, a biopsia excisional, embora um procedimento invasivo e com resultado estético inferior, tem vantagens em termos de taxa de cura e diagnóstico de certeza da presença ou não de tumor.

No presente estudo, as lesões tratadas foram avaliadas clinicamente e por exame histopatológico, por biopsia excisional, três meses após a TFD, período usado na maioria dos protocolos de estudo. A acurácia geral da avaliação clínica foi baixa, com número elevado de falsos negativos. Das vinte lesões que foram diagnosticadas clinicamente como resposta completa ao tratamento, ou seja, aparentemente curadas, seis (30\%) demonstravam tumor na biopsia, ou seja, um número significativo de falsos negativos. Como resultado, a sensibilidade da avaliação clínica pós-TFD foi baixa (65,3\%). A especificidade, entretanto, foi elevada $(93,3 \%)$, com apenas $10 \%$ de falsos positivos.

Esse resultado destaca a limitação do critério clínico de cura com a TFD. Entretanto, o exame clínico tem a vantagem de ser não invasivo, além de ter sua limitação reduzida com a avaliação periódica subsequente e cautela na interpretação. 
É possível que os efeitos cosméticos da TFD melhorem o aspecto da pele e expliquem a elevada taxa de falsos negativos, ou seja, o percentual elevado de detecção de tumor na biopsia de áreas com aparência clínica livre de CBC. A inflamação acarretada pela TFD e posterior fibrose pode mascarar a presença de tumores (FANTINI et al, 2011). Além disso, o rejuvenescimento cutâneo pelo aumento das fibras colágenas e diminuição do grau de elastose na derme subjacente, com aumento de marcadores de neocolagênese como o pró-colágeno-I e MMP-1 (TOREZAN,2011), podem melhorar o aspecto da pele e contribuir para as falhas diagnósticas. Esse efeito cosmético foi encontrado também em estudo que utilizou Nano-ALA-TFD em campo de cancerização, mostrando superioridade desse agente em relação ao M-ALA (PASSOS et al, 2012).

Na maioria dos estudos que avaliam a eficácia da TFD no CBC, após a avaliação em três meses, é feito acompanhamento clinico periódico e, havendo suspeita de presença de tumor,realizada nova biopsia. Em caso de diagnóstico de tumor, a maioria dos autores denomina essas lesões de recorrências ou de recidivas, enquanto outros autores ponderam a possibilidade de falha primária do tratamento.

Nos estudos de terapia fotodinâmica em CBC, o número total de recorrências é maior quanto mais longo o tempo de seguimento, havendo aumento cumulativo de recidivas com o tempo (FELíCIO et al, 2008; RHODESet al, 2007). Considerando o crescimento em geral lento do CBC, é possível compreender esse fenômeno, assim como supor que falhas terapêuticas com TFD são subdiagnosticadas, a depender da duração do estudo e do método de avaliação empregado. Em outras palavras, estudos com curto tempo de seguimento ou com critério de cura apenas clínico, sem biopsia, podem resultar em falsos negativos quanto à presença de tumores.

No presente estudo, apesar da avaliação da eficácia da TFD ter sido feita após três meses, tempo que pode ser considerado curto para avaliar as recorrências ou recidivas tardias, o método de avaliação estudado foi a biopsia excisional que, como já foi dito, é padrão ouro para o diagnóstico de presença ou não de tumor. Portanto, apesar do tempo relativamente curto de seguimento, a 
escolha de método diagnóstico de elevada acurácia permite avaliar com segurança o resultado da TFD no presente estudo.

\subsection{Eficácia do tratamento}

A taxa global de cura histológica com a TFD nesse estudo foi de $50 \%$. No grupo tratado com Nano-ALA o índice de cura histológica foi de $35,7 \%$ e no grupo tratado com M-ALA foi de 62,5\%. Apesar da aparente superioridade do M-ALA, a diferença encontrada não é significativa do ponto de vista estatístico, com $p=0,27$.

A comparação direta desses resultados com a literatura não é simples, pois as taxas de cura descritas em outros estudos são bastante diversas (FANTINI et al, 2011). Entretanto, de forma geral, pode se afirmar que a taxa global de cura encontrada no presente estudo é semelhante à taxa $53 \%$ de clareamento completo das lesões, que foi obtida por média ponderada a partir dos dados de 12 estudos com ALA-TFD e M-ALA-TFD no CBC nodular, com período de seguimento entre 3 e 36 meses (BABILAS et al, 2010).

A variabilidade dos resultados dos diferentes estudos reflete em parte as diferenças metodológicas, como por exemplo, o protocolo de aplicação da TFD, os diferentes critérios de inclusão (tipo de tumor tratado) e a variação no critério de cura (tempo e tipo de avaliação, ou seja, clínica ou histológica). Como resultado, há significativa amplitude das taxas de cura relatadas nos estudos com TFD no CBC nodular.

Um estudo randomizado controlado com placebo, duplo cego, realizado em dois centros, com um total de 160 lesões de CBC nodular, mostrou resposta histológica completa avaliada por biopsiaexcisional em $73 \%$ dos casos tratados com M-ALA-TFD, versus 27\% das lesões tratadas com placebo-TFD (FOLEY et al, 2009). Outro estudo que revelou taxa de resposta elevada foi o conduzido por Rhodes e colaboradores (2007), no qual foi feito acompanhamento por cinco anos de 53 
lesões de CBCn tratadas com M-ALA-TFD, sendo encontrada uma taxa de remissão de $76 \%$, utilizando critério clínico de cura.

Entretanto, há estudos com resultados com M-ALA-TFD inferiores aos descritos acima, com taxas de cura mais baixas. Em uma série de 79 lesões de CBC nodular tratadas com M-ALA-TFD a taxa de resposta completa, definida por critério clínico e não histológico, foi de 33\%, em acompanhamento semestral variando de 6 a 84 meses no total (FANTINI et al, 2011).

Tais estudos exemplificam a variabilidade dos resultados com M-ALATFD no tratamento do CBC nodular, assim como mostram que os resultados obtidos na presente pesquisa encontram-se na faixa de sucesso terapêutico relatada na literatura. Quanto ao resultado com Nano-ALA obtido no presente estudo, não é possível comparar com outros trabalhos, pois ainda não há publicação com esse agente na TFD para tratamento do CBC nodular. Entretanto, ao se considerar os resultados com ALA-TFD no CBCn, o índice de cura encontrado com Nano-ALA também encontra-se na faixa encontrada na literatura, descrita por alguns autores entre 10 e 75\% (BLUME; OSEROFF, 2007).

Além do índice de cura histológica, a variação da espessura do tumor com a TFD também foi analisada nessa pesquisa. No total, houve redução significativa da espessura do tumor após a TFD, com média pré-tratamento de $1,18 \mathrm{~mm}$ e $0,72 \mathrm{~mm}$ pós-tratamento $(p=0,0003)$. A redução do tamanho do tumor após a TFD sugere a existência de uma resposta parcial ao tratamento e apóia a ideia já documentada em revisões sistemáticas que a efetividade da TFD depende fortemente do número de ciclos terapêuticos, o que aumenta a sobrevida livre de tumor para 76 a $84 \%$ (ROOZEBOOM et al, 2013).

A variação da espessura do tumor com a TFD, um desfecho secundário no presente estudo, foi diferente nos dois grupos de tratamento, com superioridade do M-ALA em relação ao Nano-ALA. No grupo tratado com M-ALA, e não no grupo de Nano-ALA, houve redução significativa da espessura do tumor, com $p<0,001$. Entretanto, esses resultados devem ser interpretados com cautela. Em 
primeiro lugar, trata-se de um desfecho secundário. Embora a redução da espessura do tumor esteja relacionada à ação do agente fotossensibilizante e, portanto, à eficácia do tratamento, ela não é o objetivo primário da TFD, que seria de fato a cura histológica. Em segundo lugar, é possível que outros fatores relacionados à composição dos grupos de estudo tenham de certa forma prejudicado os resultados com Nano-ALA, que serão discutidos a seguir.

Um fator que pode ter prejudicado em parte o resultado do grupo NanoALA foi uma tendência de superioridade numérica de lesões em áreas de alto risco nesse grupo. Apesar da alocação dos pacientes nos dois grupos ter sido aleatória e, de fato, não tenha sido observada diferença estatisticamente significativa entre os dois grupos, 64,3\% das lesões tratadas com Nano-ALA encontravam-se em áreas de alto risco versus $31,2 \%$ das lesões do grupo tratado com M-ALA. Em outras palavras, havia um número maior de lesões de pior prognóstico no grupo de NanoALA, fator preditor de má resposta observado inclusive no presente estudo, onde se observou uma taxa global de cura histológica nas lesões em áreas de alto risco de $14,3 \%$ versus $81,3 \%$ nas áreas de baixo risco.

Um segundo fator que eventualmente pode ter prejudicado o resultado do grupo tratado com o Nano-ALA foi a detecção de variantes histológicas distintas do CBC nodular na biopsia pós-tratamento nesse grupo, com 4 das 14 lesões apresentando outros tipos de CBC (dois do tipo pigmentado, um multifocal e um do tipo adenóide). $O$ diagnóstico final de um tipo histológico distinto do $\mathrm{CBC}$ nodular ocorreu apenas no grupo tratado com Nano-ALA, ou seja, nenhum caso ocorreu no grupo tratado com M-ALA ( $p=0,03$; teste exato de Fisher). Embora o estudo seja randomizado, essa diferença pode ser explicada pelo número relativamente pequeno da amostra, o que aumenta as chances teóricas de desequilíbrio entre os grupos de estudo.

A detecção de tipos e subtipos histológicos distintos de CBC nodular na biopsia final pode ser explicada pela realização da biopsia inicial por punch, o que não representa a totalidade de um tumor que sabidamente pode apresentar associação de subtipos histológicos em uma mesma lesão. Dos casos de CBC, 37 a 
43\% podem apresentar um padrão misto de subtipos histológicos, embora exista clara predominância de um deles (CHINEM; MIOT, 2011; IZIKSON et al, 2010; WOLBERINCK et al, 2013).

A acurácia da biopsia por punch no CBC varia de acordo com o tipo histológico do tumor. Em um estudo com 500 lesões de CBC primário, Wolberink et al (2013) avaliaram a precisão da biopsia por punch em comparação com a biopsiaexcisional para identificar subtipos histológicos. Os autores encontraram uma acurácia elevada nos tipos simples, de $84 \%$, e apenas $37 \%$ de precisão nos tumores mistos. A acurácia variou também em relação ao tipo histológico, sendo maior no tipo superficial (84\%), seguida do infiltrativo (69\%), nodular (63\%) e micronodular (38\%). Os autores destacaram ainda que em $11 \%$ do total de caso um tipo mais agressivo, não suspeitado pela biopsia por punch, foi encontrado.

É possível que os tipos histológicos distintos encontrados no grupo tratado com Nano-ALA tenham pior susceptibilidade à TFD e, portanto, tenham prejudicado o resultado geral de eficácia nesse grupo. Essa possibilidade é corroborada por estudos que sugerem que a presença de subtipos agressivos não diagnosticados na biopsia inicial por punch podem explicar falhas terapêuticas com tratamentos não invasivos, como a TFD e o imiquimode (WOLBERINK et al, 2013).

O tipo histológico do CBC é um fator preditor de resposta terapêutica à TFD. O CBC superficial responde significativamente melhor à TFD que os outros tipos histológicos, com relatos de cura bastante elevados, de 87 a 100\%, tornando a TFD um tratamento recomendado nessa situação (PASSOS, 2012; MORTON et al, 2013). No CBC nodular a taxa de cura é menor, entre 10 e 76\% (FANTINI et al, 2011), sendo a TFD recomendada apenas para os tumores finos. $E$ nos outros subtipos, agressivos ou mistos, os resultados são ainda piores, havendo recomendação de evitar a TFD nesses casos (MORTON et al, 2013, ROOZEBOOM et al, 2013).

Um estudo que exemplifica a relação entre o subtipo histológico e a taxa de cura foi realizado por Horn et al (2003). Os autores pesquisaram a eficácia 
da M-ALA-TFD em 123 lesões de CBC de difícil tratamento cirúrgico, com risco de complicações ou resultado estético ruim, definidas como lesões grandes, recorrentes, em áreas centrais da face ou em pele com dano solar grave. As lesões foram tratadas com M-ALA e a taxa de remissão em três meses foi de $92 \%$ para o CBC superficial, $87 \%$ para o nodular e $57 \%$ para o tipo misto.

Diante do exposto, conclui-se que a biopsia por punch pode falhar na identificação do subtipo histológico do CBC em comparação à biopsia excisional. Isso explica a inclusão inadvertida de tipos e subtipos histológicos distintos do CBCn no estudo, fator que pode explicar falhas terapêuticas por se tratar de tipos histológicos mais agressivos e de pior resposta à TFD. Por esse motivo, é possível que a detecção de quatro lesões com menor potencial de resposta à TFD apenas no grupo tratado com Nano-ALA tenha contribuído para os resultados que apontam superioridade do M-ALA considerando o critério de redução do tumor.

Algumas vantagens do M-ALA em relação ao ALA têm sido relatadas, tais como: (1) perfil de permeação superior ao atravessar o extrato córneo e as membranas celulares; (2) maior seletividade (por exemplo, em ceratoses actínicas solares; (3) maior formação de PplX conduzindo a uma maior eficiência de fluorescência e fotodinâmica; (4) menos dor e menos efeitos sistêmicos após o tratamento local; (5) depuração mais rápida de células e tecidos (KRAMMER; VERWANGER, 2009).

Apesar dessas vantagens do M-ALA em relação ao ALA, do ponto de vista clínico, ou seja, em termos de resultados de eficácia e tolerabilidade na TFD do CBC, a questão ainda não está resolvida, devendo ser destacada a escassez de estudos diretos comparativos entre os agentes, que, entretanto, não mostram diferenças significativas (CHRISTENSEN; MØRK; SKOGVOLL, 2012;ROOZEBOOM et al, 2013).

Um exemplo da semelhança clínica entre esses agentes foi observado em um estudo randomizado, duplo-cego, que comparou a eficácia e tolerabilidade do M-ALA versus o ALA no tratamento do CBC nodular com TFD. Participaram do 
estudo 43 pacientes, que foram avaliados por biopsia oito semanas após as sessões de TFD. O resultado foi muito semelhante nos dois grupos, com aproximadamente $72 \%$ de resposta nos dois grupos, assim como escore de dor sem diferença significativa. Vale salientar que os autores relataram que na época do estudo o custo do M-ALA era aproximadamente seis vezes maior (KUIJPERS et al, 2006).

Atualmente, apenas o M-ALA tem aprovação por agências regulatórias nos EUA, Europa e Brasil para o tratamento do CBC. O ALA ainda não tem aprovação, o que se ocorresse reduziria significativamente o custo da TFD. Entretanto, é necessário realizar mais estudos comparativos entre esses agentes, inclusive abordando aspectos de fármaco-economia, a fim de esclarecer melhor a eficácia, tolerabilidade e custo-efetividade da TFD.

Uma nova perspectiva na TFD é o uso do Nano-ALA. Esse agente mostrou excelentes resultados no tratamento da Doença de Bowen, ceratose actínica e CBC superficial. Passos (2012) encontrou taxas de cura clínica de CBC superficial de $91 \%$ e $97 \%$ em 3 e 12 meses respectivamente. Na doença de Bowen, os resultados também foram expressivos, com $87 \%$ e $100 \%$ de cura em 3 e 21 meses respectivamente, o que supera os resultados descritos por outros autores com M-ALA, com taxa de recorrência de aproximadamente 15\%.

No presente estudo, os resultados encontrados com Nano-ALA foram bons, com taxa de cura histológica em três meses semelhante, do ponto de vista estatístico, ao grupo tratado com M-ALA. Embora tenha ocorrido vantagem do MALA em relação a espessura do tumor residual após o tratamento, os resultados encontrados com o Nano-ALA são promissores e justificam a realização de novos estudos, moleculares e clínicos, e com número maior de pacientes, a fim de esclarecer melhor a questão. 


\subsection{Preditores de resposta}

Foram estudados os fatores que eventualmente influenciaram a resposta ao tratamento na presente pesquisa. Para tanto, foi analisada a associação entre o desfecho histológico e algumas variáveis pré-tratamento. Entre os fatores estudados, houve apenas associação significativa entre a localização da lesão em área de alto ou baixo risco, com número maior de lesões curadas quando localizadas em área de baixo risco, com taxa global de cura histológica nas lesões em áreas de alto risco de $14,3 \%$ versus $81,3 \%$ nas áreas de baixo risco.

A localização do tumor em áreas classificadas como de alto risco é um fator bem definido de pior prognóstico de uma forma geral para o CBC, com menor taxa de cura e maior recidiva (EUROPEAN DERMATOLOGY FORUM, 2012). Um dos fatores que pode explicar o pior prognóstico global dessas lesões é o aumento da frequência de subtipos histológicos mais agressivos nessas áreas. Há aumento dos tipos nodular ou morfeico/infiltrativo nas áreas denominadas de alto risco, em comparação ao tipo superficial, um subtipo que apresenta melhor prognóstico (BETTI et al, 2010).

Entretanto, a maior ocorrência de subtipos agressivos em áreas de alto risco não explica os resultados encontrados no presente estudo, no qual todas as lesões tratadas tiveram o mesmo diagnóstico preliminar, que foi de CBC nodular. Assim, o resultado encontrado, que indica que a localização da lesão em área de alto risco é preditor de má resposta à TFD, aponta para a provável existência de fatores biológicos de maior agressividade e resistência à TFD nesses tumores especificamente. Ainda não são conhecidos marcadores genéticos ou moleculares de agressividade do tumor associados a tipos histológicos especificamente, mas é possível que pesquisas no futuro os identifiquem.

Não foram encontrados outros preditores de resposta na presente pesquisa, fenômeno que foi encontrado também em outros estudos (HORN et al, 2003; FERNÁNDEZ-GUARINO et al, 2014). A idade do paciente, o tamanho da lesão e a espessura do tumor não tiveram correlação com o desfecho histológico, e 
deve ser levada em consideração a hipótese que isso seja consequência do tamanho pequeno da amostra, o que compromete a análise com estratificação dos grupos e principalmente uma análise multivariada.

O tamanho da lesão e a espessura do tumor na avaliação histológica são considerados fatores bem documentados de pior prognóstico no CBC de uma maneira geral (EUROPEAN DERMATOLOGY FORUM, 2012). Em estudos com TFD, essa associação também já foi documentada (MATEl et al, 2013). Tumores profundos estão relacionados à menor eficácia da TFD no CBC, provavelmente pela limitação da penetração do agente fotossensibilizante e da luz.

Outros estudos, de forma indireta, também mostram associação entre pior resposta à TFD e espessura do tumor, ao demonstrarem que a redução da espessura do tumor por shaving pŕe-TFD resulta em maior índice de cura (ROOZEBOOM et al, 2013; THISSEN; SCHROETER; NEUMANN, 2000).

Entretanto, no presente estudo, nem a espessura e nem o tamanho da lesão se correlacionaram com o desfecho do tratamento. Devem ser considerados para esse resultado, além do tamanho pequeno da amostra, os critérios de inclusão utilizados. A lesões tratadas tinham no máximo $2 \mathrm{~cm}$ de diâmetro e $2 \mathrm{~mm}$ de espessura, com média de $9 \mathrm{~mm}$ de diâmetro e $1,17 \mathrm{~mm}$ de espessura. Portanto, eram todas lesões relativamente pequenas, e como o tamanho da amostra era pequeno e com variação estreita, torna-se difícil detectar eventuais diferenças significativas ao se estratificar os grupos de tratamento.

\subsection{Efeitos adversos da TFD com Nano-ALA e M-ALA}

Dor, eritema e edema são efeitos adversos esperados na TFD e estão relacionados ao mecanismo de ação do tratamento, que envolve morte celular por necrose e apoptose. Há lesão celular e tecidual promovida por oxigênio singleto $\left({ }^{1} \mathrm{O}_{2}\right)$ 
e radicais livres, como os radicais superóxido, hidroxila e peróxido (TOREZAN, 2011; LOVELL et al, 2010), o que contribui para a ocorrência de dor com o tratamento.

O mecanismo da dor provavelmente envolve a estimulação nervosa por meio de receptores localizados em terminações de fibras mielinizadas do tipo delta $A$ e não-mielinizadas do tipo $\mathrm{C}$ do nervo, que ocorre pelo dano tecidual e inflamação criados na reação fotodinâmica, e agravados pela hipertermia (CHAVES et al, 2012; MORTON et al, 2013).

A lesão fototóxica também promove processo inflamatório local, importante para a recuperação da homeostase local e cicatrização assim como para a resposta terapêutica imune mediada (KORBELIK; SUN, 2006). A inflamação, entretanto, resulta clinicamente em eritema e edema, também é fator que contribui para a ocorrência de dor. Em geral, a recuperação se dá em duas semanas a três semanas (FELÍClO et al, 2008; ISSA; AZULAY, 2010). Alterações pigmentares são raras e transitórias, assim como a alopecia local (BABILAS et al, 2010).

Todos os pacientes que participaram da pesquisa experimentaram algum grau de dor e apresentaram sinais variáveis de eritema e edema com 0 tratamento. A variação do escore de dor relatado pelos pacientes foi grande, de 1 até 10, mas em geral houve tolerância satisfatória à dor, com média global de 4,4 na primeira sessão e 5,8 na segunda sessão, quantificada por escala numérica verbal de 0 a 10.

A dor é o evento adverso mais importante da TFD, tanto pela intensidade que pode alcançar quanto pela elevada frequência, ocorrendo em mais de $90 \%$ dos casos. Apesar de durar de poucos minutos a algumas horas após a iluminação e em geral ser bem tolerada (VAN OOSTEN; KUIJPERS; THISSEN, 2006), ela pode ser intensa e comprometer a adesão do paciente, embora isso ocorra raramente, em aproximadamente $2 \%$ dos casos. (BABILAS et al, 2010).

No presente estudo, um fator determinante na redução da dor foi o resfriamento da área, considerado o mecanismo mais efetivo na analgesia para a 
TFD (BABILAS et al, 2010). Não foram utilizados anestésicos tópicos como por exemplo,prilocaína ou lidocaína, pela baixa eficácia e pela possibilidade do elevado $\mathrm{pH}$ dessas substâncias poderem inativar quimicamente o fotossensibilizante. Além do mais, alguns anestésicos tópicos podem induzir vasoconstrição e, com isso, reduzir o efeito da TFD dependente de formas reativas de oxigênio (HOLMES et al, 2004).

Para o resfriamento da pele e redução da dor com a TFD foi utilizado, na presente pesquisa, jato de ar frio do aparelho Sbirian (Inustra). O ar frio pode reduzir o metabolismo local e diminuir o dano tecidual promovido pela TFD. $O$ ar frio também estimula as fibras nervosas do tipo delta $A$ que ativam mecanismo inibitório de dor e elevam o limiar da mesma. Outros responsáveis pela melhora da dor com ar frio são os receptores de frio e mentol, conhecidos como TRPM8, que promovem analgesia nas fases iniciais da inflamação. O resfriamento reduz a dor e parece não reduzir a eficácia da TFD (PAGLIARO et al, 2004), havendo, no entanto, controvérsias a esse respeito (CHAVES et al, 2012).

A intensidade da dor pode estar relacionada ao agente utilizado, sendo que alguns estudos mostraram que M-ALA-TFD era menos doloroso do que ALATFD (BABILAS et al, 2010). Entretanto, há divergências nesse aspecto na literatura, e outros estudos não observaram essa diferença (KUIJPERS et al, 2006).

Alguns estudos de TFD no tratamento de ceratose actínica em campo de cancerização mostraram menor intensidade da dor com M-ALA comparado ao ALA. Um estudo com 69 pacientes mostrou que 54\% dos pacientes tratados com ALA e $14 \%$ dos tratados com M-ALA apresentavam dor muito intensa, com escore 10 em escala visual analógica (0-10) e descrita como "a pior dor imaginável" (KASCHE et al, 2006). Uma hipótese para esses resultados é que o ALA, ao contrário do M-ALA, é transportado até as terminações nervosas livres via os receptores de GABA (RODRIGUEZ et al, 2006).

Por outro lado, nos estudos comparativos entre ALA e M-ALA no tratamento do CBC por TFD, a eventual superioridade do M-ALA em termos de dor 
não está definida. Por exemplo, um estudo randomizado, duplo-cego, com 43 pacientes tratados com TFD para CBC nodular, não encontrou diferença significativa nos escores de dor entre o grupo tratado com Nano-ALA e no grupo com M-ALA (KUIJPERS et al, 2006).

No presente estudo, não houve diferença significativa no escore de dor entre os grupos tratados com Nano-ALA ou com M-ALA, tanto na primeira quanto na segunda sessão. Hipoteticamente, isso pode decorrer de uma menor diferença de dor entre os fotossensibilizantes quando a TFD é feita em áreas pequenas, como no CBC, ao contrário do campo de cancerização, onde a área é significativamente maior. Adicionalmente, uma segunda hipótese é que o Nano-ALA pode provocar menos dor que o ALA. Essa hipótese é reforçada por um estudo comparando NanoALA e M-ALA em TFD de campo de cancerização, em que não houve diferença estatística na intensidade de dor utilizando os dois precursores fotossensibilizantes (PASSOS et al, 2012).

Ao se comparar o escore de dor na primeira e na segunda sessão de TFD, houve diferença significativa no grupo tratado com Nano-ALA ( $p=0,02)$. Nesse grupo, a média do escore de dor na primeira sessão foi de 4,5, aumentando para 6,3 na segunda sessão. Não houve diferença significativa quanto a dor entre as sessões no grupo tratado com M-ALA $(p=0,09)$.

A maior intensidade de dor na segunda sessão de TFD no tratamento do CBC foi relatada em outros estudos, porém a explicação para esse fenômeno ainda não está esclarecida (CHAVES et al, 2012). É possível imaginar que na segunda sessão, realizada uma semana após a primeira, a lesão tecidual e inflamação remanescente da primeira sessão tornem a área mais sensível. Pode ser ainda levantada a hipótese de que a penetração do agente fotossensibilizante seja maior na segunda sessão, talvez pela vasodilatação, pelo possível afilamento do extrato córneo ou pelo dano tecidual existente. Uma terceira possibilidade que pode ser aventada é que a lesão dos tecidos seria maior na segunda sessão, seja pela maior penetração do fármaco, seja pela presença de vasodilatação, que poderia 
aumentar o dano mediado por formas reativas de oxigênio. Entretanto, essas são hipóteses ainda não testadas.

Em relação aos escores de edema e eritema, avaliados pela pesquisadora de forma não cega em escala semiquantitativa de 1 a 4 após as duas sessões, não houve diferença significativa entre os dois grupos de tratamento, assim como não houve diferença significativa em relação à intensidade desses sinais entre a primeira e a segunda sessão. Não houve ocorrência de crostas, infecção, ulceração ou outros eventos adversos durante o estudo. 


\section{CONCLUSÕES}

- A taxa global de cura, de aproximadamente $50 \%$, é semelhante a resultados encontrados na literatura e reforça que a TFD no tratamento do CBC nodular deve ser indicada em casos selecionados, embora usada com cautela.

- As taxas de cura histológica com os dois precursores fotossensibilizantes estudados, o Nano-ALA e o M-ALA, foram semelhantes.

- O perfil de toxicidade entre os dois agentes foi semelhante, havendo tolerabilidade satisfatória para ambos.

- A acurácia da avaliação clínica após a TFD para diagnosticar a presença de tumor foi baixa e resultou em $30 \%$ de falsos negativos nos casos em que clinicamente se suspeitava de cura.

- O único preditor de resposta observado foi a localização do tumor em área de alto ou baixo risco. 


\section{REFERÊNCIAS}

AGOSTINIS, P. et al. Photodynamic Therapy of Cancer: An Update. CA Cancer J Clin, v. 61, n. 4, p. 250-281, 2011.

ARAÚJO, L. M.; THOMAZINE, J. A.; LOPEZ, R. F. Development of microemulsions to topically deliver 5-aminolevulinic acid in photodynamic therapy. European Journal of Pharmaceutics and Biopharmaceutics, v. 75, n. 1, p. 48-55, 2010.

BABILAS, P. et al. Photodynamic therapy in dermatology. State-of-the-art. Photochem Photbiol Photomed, v. 26, n. 3, p. 118-32, 2010.

BARRY, B. W. A. Novel mechanisms and devices to enable succesful transdermal delivery. Eur J Pharm Sci, v. 14, p. 102-114, 2001.

BATH-HEXTALL, F. J. et al. Interventions for basal cell carcinoma of the skin. Cochrane Database Syst Rev. n. 1, CD003412, 2007.

BERTOLINI, W. L. H. M. A influência do D-limoneno como promotor de absorção de ácido 5-aminolevulínico para Terapia Fotodinâmica do câncer de pele: avaliação in vitro e in vivo da permeação e retenção cutâneas. 2009. Tese (Doutorado em Medicamentos e Cosméticos) - Faculdade de Ciências

Farmacêuticas de Ribeirão Preto, Universidade de São Paulo, Ribeirão Preto, 2009.

BETTI, R. et al. Anatomic location of Basal cell carcinomas may favor certain histologic subtypes. J Cutan Med Surg, v. 14, n. 6, p. 298-302, 2010.

BLUME, J. E.; OSEROFF, A. R. Aminolevulinic acid photodynamic therapy for skin cancers.Dermatol Clin, v. 25, n. 1, p. 5-14, 2007.

BRAATHEN, L.R. et al. Guidelines on the use of photodynamic therapy for nonmelanoma skin cancer: an international consensus. International Society for Photodynamic Therapy in Dermatology, 2005. J Am Acad Dermatol, v. 56, n. 1, p. 125-43, 2007.

CABRERA, T. et al. HLA molecules in basal cell carcinoma of the skin. Immunology, v. 185 , n. 5 , p. $440-52,1992$.

CALZAVARA-PINTON, P. G.; VENTURINI, M.; SALA, R. Photodynamic therapy: update 2006. Part 1: Photochemistry and photobiology. J Eur Acad Dermatol Venereol. v. 21, n. 3, p. 293-302, 2007.

CASTANO, A. P. ; DEMIDOVA, T. N.; MICHAEL, R. H. A Mechanism in Photodynamic Therapy: part two - cellular signaling, cell metabolism and modes of cell death. Photodiagnosis and PhotodynamicTherapy, v. 2, n. 1, p. 1-23, 2005a. 
CASTANO, A. P. ; DEMIDOVA, T. N.; MICHAEL, R. H. Mechanisms in Photodynamic therapy: Part three -Photosensitizer pharmacokinetics, biodistribution, tumor localization and modes of tumor destruction. Photodiagnosis and Photodynamic Therapy,v. 2, n.2, p. 91-106, 2005b.

CATTANEO, A. G. et al. Nanotechnology and human health: risks and benefits. $\mathbf{J}$ Appl Toxicol, v. 30, n. 8, p. 730-44, 2010.

CHAVES, Y. N. et al. Dor na terapia fotodinâmica: mecanismo de ação e estratégias de manejo. An Bras Dermatol, v. 87, n. 4, p. 521-9, 2012.

CHINEM, V. O.; MIOT, H. A. Epidemiologia do carcinoma basocelular. An Bras Dermatol, v. 86, n. 2, p. 292-305, 2011.

CHORILLI, M. et al. Aspectos gerais em sistemas transdermicos de liberacão de farmacos. Rev Bras Farm, v. 88, n. 1, p. 7-13, 2007.

CHRISTENSEN, E.; MØRK, C.; SKOGVOLL, E. High and sustained efficacy after two sessions of topical 5-aminolaevulinic acid photodynamic therapy for basal cell carcinoma: a prospective, clinical and histological 10-year follow-up study. British Association of Dermatologists , v. v. 166, n. 6, p. 1342-1348, 2012.

CIUREA, M. E. et al. Expression of CXCR4, MMP-13 and $\beta$-catenin in different histological subtypes of facial basal cell carcinoma. Rom J Morphol Embryol, v. 54, n. 4., p. 939-951, 2013.

COSGAREA, R. et al. Photodynamic therapy using 5-aminolevulinic acid vs. surgery for Basal Cell Carcinoma. J Eur Acad Dermatol Venereol, v. 27, n. 8, p. 980-984, 2013.

DE ROSA, F. S. et al. A vehicle for photodynamic therapy of skin cancer: influence of dimethylsulphoxide on 5-aminolevulinic acid in vitro cutaneous permeation and in vivo protoporphyrin IX accumulation determined by confocal microscopy. J Control Release, v. 65, n. 3, p. 359-66, 2000.

DE ROSA, F. S. et al. In vitro skin permeation and retention of 5-aminolevulinic acid ester derivatives for photodynamic therapy. J Control Release, v. 89, n. 2, p. 261-9, 2003.

DELOUISE, L. A. Applications of nanotechnology in dermatology. J Invest Dermatol, v. 132, n. 3, pt. 2, p. 964-75, 2012.

DOUGHERTY, T. J. et al. Photodynamic therapy. J Natl Cancer Inst, v. 90, n. 12, p., 889-905, 1998.

DOUGHERTY, T. J.; KAUFMANN, J. E.; GOLDFARB, A. Photoradiation therapy for the treatment of malignant tumors. Cancer Res, v. 38, n. 8, p. 2628-35, 1978. 
European Dermatology Forum. Guidelines on Basal Cell Carcinoma (Update 2012). Disponível em http://www.euroderm.org/images/stories/guidelines/guideline_Basal_Cell_Carcinomaupdate2012\%20.pdf. Acesso em 28/11/2014.

FANTINI, F. et al. Photodynamic therapy for basal cell carcinoma: clinical and pathological determinants of response. J Eur Acad Dermatol Venereol, v. 25, n. 8, p. 896-901,2011.

FELÍCIO, L. B. A. et al. A terapia fotodinamica com acido 5-aminolevulinico como modalidade de tratamento para neoplasias cutaneasnao-melanoma. An Bras Dermatol, v. 83, n. 4, p. 309-16, 2008.

FERNÁNDEZ-GUARINO, M. et al. Six years of experience in photodynamic therapy for Basal cell carcinoma: results and fluorescence diagnosis from 191 lesions. J Skin Cancer, 2014:849248, 2014. Disponível em:

http://www.ncbi.nlm.nih.gov/pmc/articles/PMC4180200/. Acessado em 28/11/2014.

FOLEY, P. et al. Photodynamic therapy with methyl aminolevulinatefor primary nodularbasal cell carcinoma: results of two randomized studies. Int J Dermatol, v. 48, n. 11, p. 1236-45, 2009.

GAULLIER, J. M.Use of 5-aminolevulinic acid esters to improve photodynamic therapy on cells in culture. Cancer Research, v. 57, n. 8, p. 1481-1486,1997.

GEDERAAS, O. A. et al. 5-aminolaevulinic acid methyl ester transport on amino acidcarriers in a human colon adenocarcinoma cell line. Photochemistry and Photobiology, v. 73, n. 2, p. 164-169, 2001.

GERRITSEN, M. J. et al. Pretreatment to Enhance PpIX Accumulation in Photodynamic Therapy. Dermatology; v. 218, n. 3, p. 193-202, 2009.

GUPTA, A. K; RYDER, J. E. Photodynamic Therapy and Topical Aminolevulinic Acid: an overview. Am J Clin Dermatol, v. 4, n. 10, p. 699-708, 2003.

HACKER, S. M.; BROWDER, J. F.; RAMOS-CARO, F. A. Basal cell carcinoma. Chosing the best method of treatment for a particular lesion. Posgrad Med, v. 93, n. 8, pp 101-104, 106-108, 111, 1993.

HADJUR, C. et al.Photodynamic effects of hypericin on lipid peroxidation and antioxidant status in melanoma cells. Photochem Photobiol, v. 64, n. 2, p. 375-381,1996.

HENDERSON, B.W.; BUSCH, T. M.; SNYDER, J. W. Fluence rate as a modulator of PDT mechanisms. Lasers Surg Med, v. 38, n. 5, p. 489-93, 2006.

HOLMES, M. V. et al. A randomized, double-blind, placebo-controlled study of the efficacy of tetracaine gel (Ametop) for pain relief during topical photodynamic therapy.Br J Dermatol, v. 150, n. 2, p. 337-40, 2004 
HORN, M. et al. Topical methyl aminolaevulinate photodynamic therapy in patients with basal cell carcinoma prone to complications and poor cosmetic outcome with conventional treatment. Br J Dermatol, v. 149, n. 6, p. 1242-9, 2003.

INCA. Distrito Federal. Estimativas para o ano de 2014 das taxas brutas de incidência por 100 mil habitantes e do número de casos novos de câncer, segundo sexo e localização primária. Disponível em:

<http://inca.gov.br/estimativas/2003/tabelaestados.asp?UF=DF>. Acesso em $11 / 10 / 2014$.

ISSA, M. C.; AZULAY, M. Terapia fotodinâmica: revisão da literatura e documentação iconográfica. An Bras Dermatol, v. 85, n. 4, p. 501-511, 2010.

IZIKSON, L.; SEYLER, M.; ZEITOUNI,N. C. Prevalence of Underdiagnosed Aggressive Non-Melanoma Skin Cancers Treated with Mohs Micrographic Surgery: Analysis of 513 Cases. Dermatol Surg, v. 36, n. 11, p. 1769-1772, 2010.

KALKA, K.; MERK, H.; MUKHTAR, H. Photodynamic therapy in dermatology. J Am AcadDermatol, v.42, n. 3, 389-413, 2000.

KASCHE, A et al. Photodynamic therapy induces less pain in patients treated with methyl aminolevulinate compared to aminolevulinic acid. J Drugs Dermatol, v. 5, n. 4, p. 353-6, 2006.

KENNEDY, J. C.; POTTIER, R. H. Endogenous protoporphorphyrin IX, a clinical useful photosensitizer for photodynamic therapy. J Photochem Photobiol B, v. 14, n. 4, p. 275-292, 1992.

KENNEDY, J. C.; POTTIER, R. H; PROSS, D. C. Photodynamic therapy with endogenous protoporphyrin IX: basic principles and present clinical experience. $\mathbf{J}$ Photochem Photobiol B, v. 6, n. 1-2, p. 275-92,1990.

KLOEK, J.; AKKERMANS, W.; VAN HENEGOUWEN, G. M. J. B. Derivatives of 5aminolevulinic acid for photodynamic therapy: Enzymatic conversion intoprotoporphyrin. Photochemistry and Photobiology, v. 67, n. 1, p. 150-154, 1998.

KORBELIK, M.; SUN, J. Photodynamic therapy-generated vaccine for cancer therapy. Cancer Immunollmmunother, v. 55, n. 8, p. 900-909, 2006.

KRAMMER, B.; VERWANGER, T. Photodynamic therapy with aminolevulinic acid or its methyl ester: Which one is superior? Medical Laser Application, v. 24, p. 221226, 2009.

KRISHNAN et al. Enhanced sonophoretic delivery of 5-aminolevulinic acid: preliminary humanexvivopermeation data. Skin Research and Technology, v. 19, n. 1, p. e283-e289, 2013. 
KUIJPERS, D. I. et al. Similar effectiveness of methyl aminolevulinate and 5aminolevulinate in topical photodynamic therapy for nodular basal cell carcinoma. $\mathbf{J}$ Drugs Dermatol, v. 5, n. 7, p. 642-5, 2006.

LEBOIT, P. E. et al (Eds.): World Health Organization. Classification of Tumours. Pathology and Genetics of Skin Tumours. IARC Press: Lyon 2006. Disponível em: http://dc102.4shared.com/doc/VMRQWwxH/preview.html. Acessado em 16/10/2014.

LEE, W. R. et al. Fractional laser as a tool to enhance the skin permeation of 5aminolevulinic acid with minimal skin disruption: A comparison with conventional erbium:YAG laser. Journal of Controlled Release, v. 145, n. 2, p. 124-133, 2010.

LINDBERG-LARSEN, R.; SøLVSTEN, H.; KRAGBALLE, K. Evaluation of recurrence after photodynamic therapy with topical methylaminolaevulinate for 157 basal cell carcinomas in 90 patients. Acta Derm Venereol, v. 92, n. 2, p. 144-147, 2012.

LOVELL, J. F. et al. Activable photosensitizers for imaging and therapy. Chem Rev, v. 110, n. 5, p. 2839-2857, 2010.

MARMUR, E. S.; SCHMULTS, C. D.; GOLDBERG, D. J. A review of laser and photodynamic therapy for the treatmenfnonmelanoma skin cancer. Dermatol Surg, v. 30, n. 2(pt2), p. 264-271, 2004.

MATEI, C. et al. Photodynamic therapy in the treatment of basal cell carcinoma. $\mathbf{J}$ Med Life, v. 156, n. 1. p. 50-4, 2013.

MATEOIU, C.; PIRICI, A.; BOGDAN, F. Immunohistochemical nuclear staining for p53, PCNA, Ki-67 and bcl-2 in different histologic variants of basal cell carcinoma. Rom J Morphol Embryol, v. 51, suppl. 1, p. 315-319, 2011. Supplement.

MORROW, D. I. J. et al. Hexyl Aminolaevulinate Is a More Effective Topical Photosensitiser Precursor than Methyl Aminolaevulinate and 5-Aminolaevulinic Acids When Applied in Equimolar Doses. Journal of pharmaceutical sciences, $v$. 99, n. 8, p. 3486-98, 2010.

MORTON, C. A. et al. European guidelines for topical photodynamic therapy part 1: treatment delivery and current indications - actinic keratoses, Bowen's disease, basal cell carcinoma. J Eur Acad Dermatol Venereol, v. 27, n. 5, p. 536-44, 2013.

MORTON, C. A. et al. Guidelines for topical photodynamic therapy: report of a workshop of the British Photodermatology Group. Br J Dermatol, v. 146, n. 4, p. 552-67, 2002.

MORTON, C. A. Photodynamic therapy for nonmelanoma skin cancer - and more? Arch Dermatol.v. 140, n. 1, p. 116-120, 2004.

MOSTERD, K. et al. Fractionated 5-aminolaevulinic acid-photodynamic therapy vs. surgical excision in the treatment of nodular basal cell carcinoma: results of a 
randomized controlled trial. British Journal of Dermatology, v. 159, n. 4, p. 864870, 2008.

MOSTERD, K. et al. Surgical excision versus Mohs' micrographic surgery for primary and recurrent basal-cell carcinoma of the face: a prospective randomised controlled trial with 5-years' follow-up. The Lancet Oncology, v. 9, n. 12, p. 1149 - 1156, 2008.

NEL, A. et al. Toxic potential of materials at the nanolevel. Science, v. 311, n. 5761, p. $622-627,2006$

OSTLER, R. B., et al. The effect of pH on the photophysics and photochemistry of disulphonated aluminum phthalocyanine. Photochem Photobiol, v. 71, n. 4, p. 397404, 2000.

PAGLIARO, J. et al. Cold air analgesia in photodynamic therapy of basal cell carcinomas and Bowen's disease: an effective addition to treatment: a pilot study. Dermatol Surg; v. 30, n. 1, p. 63-66, 2004.

PASSOS, S. K. et al. Quantitative approach to skin field cancerization using a nanoencapsulated photodynamic therapy agent: a pilot study. Clin Cosmet Investig Dermatol, v. 6, p. 51-9, 2013.

PASSOS, S. K. Terapia fotodinâmica com ácido 5-amino-levulínico em nanoemulsão no tratamento de ceratoses actínicas e câncer de pele não melanoma: estudo clínico. 2012. Tese (Doutorado em Ciências). Faculdade de Medicina, Universidade de Brasília, Brasília, 2012.

PIERRE, M. B. et al. Potential incorporation of 5-aminolevulinic acid in micelles and stratum corneum lipids liposomes: fluorescence quenching studies. Brazilian Journal of Pharmaceutical Sciences, v. 37, p. 355-61,2001a.

PIERRE, M. B. et al. Stratum corneum lipids liposomes for the topical delivery of 5aminolevulinic acid in photodynamic therapy of skin cancer: preparation and in vitro permeation study. BMC Dermatology, v. 1, p. 5, $2001 \mathrm{~b}$.

PONTÉN, F.; LUNDEBERG, J.; ASPLUND.A. Principio da biologia tumoral e patogênese dos CBC eCEC. In. BOLONIA, J. L; JORIZO, J. L.; RAPINI, R. P. Dermatologia. Rio de janeiro: Elsevier, 2011, tradução da $2^{a}$ edição, p. 1627-1639.

PRIMO, F. L., et al. In vitro evaluation of

chloroaluminumphthalocyaninenanoemulsion and low-level laser therapy on human skin dermal equivalents and bone marrow mesenchymal stem cells. Cur Med Chem, v. 18, n. 22, p. 3376-3381, 2011.

REGO, R. F. Estudo comparativo de precursores da Protoporfirina I X (ALA e MAL) utilizados topicamente em Terapia Fotodinâmica. 2008. Dissertação (Mestrado em Biotecnologia). Universidade Federal de São Carlos, São Carlos, 2008. 
RHODES, L. E. et al. Five-year follow-up of a randomized, prospective trial of topical methyl aminolevulinate photodynamic therapy vs surgery for nodular basal cell carcinoma. Arch Dermatol, v. 143, n. 9, p. 1131-6, 2007.

RODRIGUEZ, L. et al. Mechanisms of 5-aminolevulinic acid ester uptake in mammalian cells. Br J Pharmacol, v. 147, n. 7, p. 825-833, 2006.

ROOZEBOOM, M. H. et al. Fracioned 5- Aminoacidlevulinic acid photodynamic therapy after partial debulking versus cirugical excision for nodular basal cell carcinoma. J Am Acad Dermatol, v. 69, n. 2, p. 280-286, 2013.

ROOZEBOOM, M. H. et al. Overall treatment success after treatment of primary superficial basal cell carcinoma: a systematic review and meta-analysis of randomized and nonrandomized trials. Br J Dermatol,v. 167, n. 4, p. 733-56, 2012.

ROSSI-BERGMANN, B. et al. A nanotecnologia: da saúde para além do determinismo tecnológico. Cienc Cult, v. 60, n. 2, p. 54-57, 2008.

RUD, E. et al. 5-aminolevulinic acid, but not 5-aminolevulinic acid esters, is transported into adenocarcinoma cells by system BETA transporters.

PhotochemPhotobiol, v. 71, n. 5, p. 640-7, 2000.

SALDANHA, G; FLETCHER, A; SLATER, D. N. Basal cell carcinoma: a dermatopathological and molecular biological update. Br J Dermatol, v. 148, n. 2, p. 195-202, 2003.

SAMPAIO, S.; RIVITTI, E. A. Pele normal. Anatomia e fisiologia. In: SAMPAIO, S.; RIVITTI, E. A. Dermatologia, São Paulo: Artes Médicas, 2001. 2ª Ed, parte I, p. 338.

SEKULIC, A. Efficacy and safety of vismodegib in advanced basal-cell carcinoma. $\mathbf{N}$ Engl J Med, v. 366, n. 23, p. 2171-9, 2012.

SILVA, C. L et al. Improved In vitro and In vivo Cutaneous Delivery of Protoporphyrin IX from PLGA-based Nanoparticles. Photochemistry and Photobiology, v. 89, n. 5, p. 1176-1184, 2013.

SOUZA, C. F. D. et al. Topografia do carcinoma basocelular e suas correlações com o gênero, a idade e o padrão histológico. An Bras Dermatol, v. 86, n. 2, p. 272-7, 2011.

SUZUKI, H. S. et al. Comparação do fototipo entre caucasianos e orientais. Surg Cosmet Dermatol, v. 3, n. 3, p. 193-6, 2011.

TELFER, N. R.; COLVER, G. B. ; MORTON, C. A.. Guidelines for the management of basal cell carcinoma. British Journal of Dermatology, v. 159, n. 1, p. 35-48, 2008. 
THISSEN, M. R.; SCHROETER, C. A.; NEUMANN, H. A. Photodynamic therapy with delta-aminolaevulinic acid for nodular basal cell carcinomas using a prior debulking technique. Br J Dermatol, v. 142, n. 2, p. 338-9, 2000.

TOREZAN, L. A. R. Estudo da pele do campo cancerizável antes e após a terapia fotodinâmica através dos métodos clínicos, histopatológicos e imunohistoquímicos. 2011. Tese (Doutorado em Dermatologia) - Faculdade de Medicina, Universidade de São Paulo, São Paulo; 2011.

TOREZAN, L. et al. A pilot split-face study comparing conventional methyl aminolevulinate-photodynamic therapy (PDT) with microneedling-assisted PDT on actinically damaged skin. Dermatol Surg, v. 39, n. 8, p. 1197-201, 2013.

TOREZAN, L. Terapia fotodinâmica: princípios de fotoquímica, fotobiologia, agentes fotossensibilizantes e aplicações na oncologia cutânea. In: Osorio, N., Torezan, L. Laser em dermatologia. 2a ed. São Paulo: Roca, 2009a. p..171-94.

TOREZAN, L., NIWA, A. B.; NETO, C. F. Terapia fotodinâmica em dermatologia: princípios básicos e aplicações. An Bras Dermatol, v. 84, n. 5, p. 445-59, 2009b.

TURCHIELLO, R. F. et al. Cubic phase gel as a drug delivery system for topical application of 5-ALA, its ester derivatives and m-THPC in photodynamic therapy (PDT). Journal of Photochemistry and Photobiology B, v. 70, n. 1, p. 1-6, 2003.

VAN OOSTEN, E. J.; KUIJPERS, D. I.; THISSEN, M. R. Different pain sensations in photodynamic therapy of nodular basal cell carcinoma Results from a prospective trial and a review of the literature. Photodiagnosis Photodyn Ther, v. 3, n. 1, p. 618, 2006.

VENA, F. C. et al. 5-Aminolevulinic acid esters-induced protoporphyrin IX in a murine melanoma cell Line. Laser in Medical Science, v. 19, n. 2, p. 119-126, 2004

WACHOWSKA, M. et al. Aminolevulinic Acid (ALA) as a Prodrug in Photodynamic Therapy of Cancer. Molecules, v. 16, n. 5, p. 4140-4164, 2011.

WEBBER, J.; KESSEL, D; FROMM, D. Plasma levels of protoporphyrin IX in humans after oral administration of 5-aminolevulinic acid. Journal of Photochemistry and Photobiology B-Biology, v. 37, n. 1-2, p. 151-153, 1997.

WOLBERINK, E. A. et al. High discordance between punch biopsy and excision in establishing basal cell carcinoma subtype: analysis of 500 cases. J Eur Acad Dermatol Venereol, v. 27, n. 8, p. 985-9, 2013.

YANG, S. J. et al. Colorectal cancer cell detection by 5-aminolaevulinic acid-loaded chitosan nano-particles. Cancer Lett, v. 273, n. 2, p. 210-220, 2009. 
ZELICKSON, B. D. Mechanisms of action of topical aminolevulinic acid. In: Goldman MP, editor. Photodynamic Therapy. 1st ed. Philadelphia: Elsevier Saunders; 2005. p. 1-12.

ZHANG, L.W., Al-Suwayeh SA, Hung CF, Chen CC, Fang JY. Oil components modulate the skin delivery of 5-aminolevulinic acid and its ester prodrug from oil-inwater and water-in-oil nanoemulsions. Int J Nanomedicine. v. 6, p. 693-704, 2011. 


\begin{abstract}
ANEXOS
Apêndice I: Termo de consentimento livre esclarecido

\section{TERMO DE CONSENTIMENTO LIVRE ESCLARECIDO}

Estudo a ser desenvolvido: "Tratamento do câncer da Pele com terapia fotodinâmica"

1. Fui convidado (a) para participar de um estudo de uso de terapia fotodinâmica para câncer da pele após ter feito biopsia incisional para confirmar meu diagnóstico e me foram dados os seguintes esclarecimentos:
\end{abstract}

\title{
Esclarecimentos:
}

2. A sessão de terapia fotodinâmica consiste na aplicação de um creme na pele, contendo uma substância (ALA ou Metil - ALA) que será transformada pelo organismo do paciente em outra substância sensível à luz, em um período de oclusão de 3 horas. Depois desse período a área tratada será exposta à luz por 8 minutos. Serão aplicadas duas sessões de terapia fotodinâmica com intervalo de sete dias, com a mesma substância (ALA ou Metil - ALA), que será escolhida no momento do tratamento, de acordo com a disponibilidade.

\section{Justificativa:}

3. Entendi que o tratamento ideal para o câncer de pele é normalmente a cirurgia, mas vou fazer a terapia fotodinâmica.
a) por escolha própria ou;
b) porque não estou em condições clínicas de fazer cirurgia; ou
c) porque tenho múltiplas lesões no rosto e no tronco.
d) outros motivos

\section{Objetivos:}

Fui informado de que os objetivos deste estudo são: 
4. Comparar a resposta terapêutica de duas substâncias fotossensibilizantes (cremes) já utilizadas na terapia fotodinâmica para tratamento de lesões malignas da pele.

\section{Procedimento:}

5. A Lesão tratada deverá ser limpa diariamente com água e sabonete e um creme deverá ser aplicado de acordo com a orientação médica.

6. Serei examinado pelo médico responsável aos 14 e 90 dias após o tratamento e serei submetido a uma biopsia excisional para garantir a minha cura. Depois desse período as consultas serão trimestrais (a cada 3 meses) no primeiro ano e semestrais (a cada 6 meses) no segundo ano. Em todas as consultas as áreas tratadas serão fotografadas para acompanhamento.

\section{Desconfortos e riscos possíveis:}

7. Entendi que durante o tratamento poderá ocorrer dor, principalmente ardência no local do tratamento, que será minimizada com uso de ar gelado gerado por um aparelho chamado Siberiam e analgésicos quando necessário.

8. Após uma sessão de terapia fotodinâmica a pele ficará avermelhada, inchada durante os primeiros dias, depois poderá surgir uma ferida superficial, depois forma casquinha, o que faz parte do tratamento

9. Entendi que este tratamento pode não levar à cura completa das lesões, assim como nos outros tratamentos preconizados.

10. Entendi que é necessário seguir as orientações do médico para evitar complicações, como a infecção da área tratada.

\section{Benefícios esperados:}

11. Foi explicado que este tratamento tem vantagens em relação à cirurgia que são: não necessitar de anestesia local, não levar corte, evitar formação de cicatrizes, a possibilidade de tratar várias lesões ao mesmo tempo, assim como repetir as sessões sem causar resistência ou exceder a dose total máxima.

\section{Forma de acompanhamento e assistência, e informações sobre os responsáveis:}

12. Entendi que após ser selecionado e ter concordado em fazer este tratamento, serei atendido por médicos do Serviço de Dermatologia do HRAN que vão fazer o tratamento e marcar as datas em que deverei voltar para fazer exames que verifiquem o progresso do tratamento. 
13. Foi garantido que receberei este tipo de terapia para tratamento de novas lesões, se for comprovada a sua superioridade.

14. Ficou esclarecido que as dúvidas sobre o tratamento e resultados serão esclarecidas a qualquer momento deste estudo.

15. Eu entendi que sou livre para me recusar a participar deste estudo ou retirar meu consentimento, em qualquer fase da pesquisa, sem penalização alguma e sem prejuízo ao meu tratamento e atendimento médico.

16. Foi garantido que os dados confidenciais envolvidos neste estudo serão mantidos sob sigilo.

17. Fui informado de que poderei entrar em contato com o Comitê de Ética em Pesquisa pelo telefone (061) 3325-4955 caso este Termo de Consentimento Livre Esclarecido não seja cumprido.

18. Fui informado de que poderei também entrar em contato com os pesquisadores responsáveis por este estudo, Dra.Roula Kozak e Prof. Zulmira Lacava, pelo telefone (061) 33461106 / 3107-3087 ou e-mail clinicavita@gmail.com, zulmira@unb.br e cnano@unb.br, caso este Termo de Consentimento Livre Esclarecido não seja cumprido ou queira receber outros esclarecimentos.

19. Uma cópia deste Termo de Consentimento Livre Esclarecido devidamente assinado por mim e pelo médico que me atendeu será mantida em meu poder.

20. Eu concordo em participar do estudo e cooperar com o médico durante as consultas e procedimentos previstos que foram a mim explicados.

Assinatura do paciente ou responsável

Nome do paciente:

Número do SES:

Data:

Nome e CRM do médico: ROULA KOZAK- CRM 8403- DF

Assinatura do Médico: 
Apêndice II: Modelos das tabelas usadas para coleta dos dados

Dados do paciente - Grupo (Nano-ALA ou M-ALA):

\begin{tabular}{|l|l|l|l|l|l|}
\hline Nome & $\begin{array}{c}\text { Registro } \\
\text { SES }\end{array}$ & Sexo & Idade & Fototipo & Cor dos olhos \\
\hline & & & & & \\
\hline & & & & & \\
\hline
\end{tabular}

Aspectos pré-tratamento da lesão

\begin{tabular}{|l|l|l|l|l|l|}
\hline $\begin{array}{c}\text { \#paciente e } \\
\text { iniciais }\end{array}$ & Local & $\begin{array}{c}\text { Área de } \\
\text { risco }(\mathrm{S} / \mathrm{N})\end{array}$ & $\begin{array}{c}\text { Tamanho } \\
(\mathrm{mm})\end{array}$ & $\begin{array}{c}\text { Tipo } \\
\text { histológico }\end{array}$ & $\begin{array}{c}\text { Espessura } \\
(\mathrm{mm})\end{array}$ \\
\hline & & & & & \\
\hline & & & & & \\
\hline
\end{tabular}

Aspectos pós-tratamento da lesão (90 dias após TFD)

\begin{tabular}{|c|c|c|l|c|}
\hline $\begin{array}{c}\text { \#paciente e } \\
\text { iniciais }\end{array}$ & $\begin{array}{c}\text { Suspeita clínica } \\
\text { (cura ou tumor) }\end{array}$ & $\begin{array}{c}\text { Resultado histológico } \\
\text { (cura ou tumor) }\end{array}$ & Tipo histológico & $\begin{array}{c}\text { Espessura } \\
\text { (mm) }\end{array}$ \\
\hline & & & & \\
\hline & & & & \\
\hline
\end{tabular}

Eventos adversos: Primeira sessão

\begin{tabular}{|l|l|l|l|l|l|}
\hline $\begin{array}{c}\text { \#paciente e } \\
\text { iniciais }\end{array}$ & Data & $\begin{array}{c}\text { Grupo } \\
\text { (Nano-ALA ou M-ALA) }\end{array}$ & $\begin{array}{c}\text { Dor } \\
(0-10)\end{array}$ & $\begin{array}{c}\text { Eritema } \\
(0-4)\end{array}$ & $\begin{array}{c}\text { Edema } \\
(0-4)\end{array}$ \\
\hline & & & & & \\
\hline & & & & & \\
\hline
\end{tabular}

Eventos adversos: Segunda sessão

\begin{tabular}{|c|c|c|c|c|c|}
\hline $\begin{array}{c}\text { \#paciente e } \\
\text { iniciais }\end{array}$ & Data & $\begin{array}{c}\text { Grupo } \\
\text { (Nano-ALA ou M-ALA) }\end{array}$ & $\begin{array}{c}\text { Dor } \\
(0-10)\end{array}$ & $\begin{array}{c}\text { Eritema } \\
(0-4)\end{array}$ & $\begin{array}{c}\text { Edema } \\
(0-4)\end{array}$ \\
\hline & & & & & \\
\hline & & & & & \\
\hline
\end{tabular}


Apêndice II: Ficha de coleta de dados

\section{Dados do paciente}

Nome: Idade:

Sexo Fototipo: Cor dos Olhos (claros ou escuros):

Grupo (Nano-ALA ou M-ALA) Registro SESDF:

\section{Aspectos da lesão pré-tratamento:}

Local: Área de risco $(\mathrm{S} / \mathrm{N})$ :

Tamanho (mm): Espessura (mm):

Tipo histológico:

Aspectos da lesão pós-tratamento:

Avaliação clínica (cura ou tumor):

Resultado histológico:

Espessura (mm): Tipo histológico:

Eventos adversos:

\begin{tabular}{|l|l|l|l|l|}
\hline & Data & $\begin{array}{c}\text { Dor } \\
(0-10)\end{array}$ & $\begin{array}{c}\text { Eritema } \\
(0-4)\end{array}$ & $\begin{array}{c}\text { Edema } \\
(0-4)\end{array}$ \\
\hline Primeira sessão & & & & \\
\hline Segunda sessão & & & & \\
\hline
\end{tabular}

Observações / Outros eventos adversos: 